\title{
A novel validated RP-UPLC-DAD method for the simultaneous estimation of Emtricitabine, Tenofovir Disoproxil Fumarate, Cobicistat and Elvitegravir in bulk and tablet dosage form with forced degradation studies
}

\author{
Uttam Prasad Panigrahy ${ }^{1}$, A. Sunil Kumar Reddy ${ }^{2,3}$ \\ ${ }^{I}$ Department of Pharmaceutical Analysis and Quality Assurance, Malla Reddy College of Pharmacy, \\ Maisammaguda, Secunderabad-500014, India \\ ${ }^{2}$ Department of Pharmaceutical Chemistry, Bharat Institute of Technology-Pharmacy, Ibrahimpatnam, \\ Hyderabad-501510, India \\ ${ }^{3}$ APL Research Centre-2, Aurobindo Pharma Ltd., Sanga Reddy, Medak, Telengana-502329, India
}

\begin{abstract}
The aim of the present work was to develop and validate a rapid Reverse Phase Ultra Performance Liquid Chromatographic method for the simultaneous estimation of Emtricitabine, Tenofovir Disoproxil Fumarate, Cobicistat and Elvitegravir in its bulk and tablet dosage form with forced degradation studies. The separation was performed by ACQUITY UPLC BEH $C_{18}(100 \mathrm{~mm} \times 2.1 \mathrm{~mm}, 1.7 \mu \mathrm{m}$ particle size) column, Waters ACQUITY UPLC system with PDA detector and mobile phase contained a mixture of 0.01M Ammonium acetate ( $\mathrm{pH}$ adjusted to 7.5 with ammonium hydroxide) and Acetonitrile $(45: 55, v / v)$. The flow rate was set to $0.25 \mathrm{~mL} / \mathrm{min}$ with responses measured at $268 \mathrm{~nm}$. The retention time of Emtricitabine, Tenofovir Disoproxil Fumarate, Cobicistat and Elvitegravir was $0.904 \mathrm{~min}, 1.240 \mathrm{~min}, 2.615 \mathrm{~min}$ and $3.801 \mathrm{~min}$ with resolution of $4.05,13.02$ and 8.27 respectively. Linearity was established in the range of 20-100 $\mu \mathrm{g} / \mathrm{mL}$ for Emtricitabine, 30-150 $\mu \mathrm{g} / \mathrm{mL}$ for Tenofovir Disoproxil Fumarate, 15-75 $\mu \mathrm{g} / \mathrm{mL}$ for Cobicistat and $15-75 \mu \mathrm{g} / \mathrm{mL}$ for Elvitegravir with correlation coefficients $\left(r^{2}=0.999\right)$. The percentage recoveries were between $99.55-99.96 \%$, 100.04-100.07\%, 99.86-100.09\% and 99.95-100.19\% for Emtricitabine, Tenofovir Disoproxil Fumarate, Cobicistat and Elvitegravir respectively. Validation parameters were evaluated according to the International Conference on Harmonization (ICH) Q2 R1 guidelines. The forced degradation studies were performed by using $\mathrm{HCl}, \mathrm{NaOH}, \mathrm{H}_{2} \mathrm{O}_{2}$, thermal and $\mathrm{UV}$ radiation. Emtricitabine are more sensitive towards alkaline hydrolysis degradation condition, Tenofovir Disoproxil Fumarate is more sensitive towards oxidative degradation condition, Cobicistat are more sensitive towards alkaline hydrolysis degradation condition and Elvitegravir are more sensitive towards acidic hydrolysis degradation condition. The developed method was successfully applied for the quantification and hyphenated instrumental analysis.
\end{abstract}

Keywords: Emtricitabine, Tenofovir Disoproxil Fumarate, Cobicistat, Elvitegravir, UPLC, PDA detector, Hyphenated and ICH.

\section{Introduction}

Emtricitabine, Tenofovir Disoproxil Fumarate, Cobicistat and Elvitegravir combined dosage form is used for the treatment of HIV-1infection in adult patients ${ }^{1}$. Emtricitabine, a synthetic nucleoside analog of cytidine, is phosphorylated by cellular enzymes to form emtricitabine 5'-triphosphate. Emtricitabine is 5-fluoro1-[(2R, 5S)-2- (hydroxyl methyl)-1, 3-oxathiolan-5-yl] cytosine were shown in figure 1A. Emtricitabine 5'triphosphate inhibits the activity of the HIV-1 reverse transcriptase by competing with the natural substrate deoxycytidine 5'-triphosphate and by being incorporated into nascent viral DNA which results in chain termination. Emtricitabine 5'-triphosphate is a weak inhibitor of mammalian DNA polymerases $\alpha, \beta$, $\varepsilon$, and mitochondrial DNA polymerase $\gamma$. Tenofovir Disoproxil Fumarate is a fumaric acid salt of the bis iso propoxy carbonyl oxy methyl ester derivative of tenofovir. Tenofovir Disoproxil Fumarate is 9-[(R)-2-[ [bis [ [(iso propoxy carbonyl) oxy] - methoxy] phosphinyl] methoxy] propyl] adenine fumarate were shown in figure 1B. Tenofovir Disoproxil Fumarate is an acyclic nucleoside phosphonate diester analog of adenosine monophosphate. Tenofovir Disoproxil Fumarate requires initial diester hydrolysis for conversion to tenofovir and subsequent phosphorylations by cellular enzymes to form tenofovir diphosphate. Tenofovir diphosphate inhibits the activity of HIV-1 reverse transcriptase by competing with the natural substrate deoxyadenosine 5'triphosphate and after incorporation into DNA, by DNA chain termination. Tenofovir diphosphate is a weak inhibitor of mammalian DNA polymerases $\alpha, \beta$, and mitochondrial DNA polymerase $\gamma$. Cobicistat is 1,3 -thiazol5-ylmethyl [(2R,5R)-5-\{[(2S)-2-[(methyl\{[2-(propan-2-yl)-1,3-thiazol-4-yl] methyl $\}$ carbamoyl) amino]-4(morpholin-4yl) butanoyl] amino\}-1,6-diphenylhexan-2-yl] carbamate were shown in figure 1C. Cobicistat is a 
selective, mechanism-based inhibitor of cytochromes P450 of the CYP3A subfamily. Inhibition of CYP3Amediated metabolism by cobicistat enhances the systemic exposure of CYP3A substrates, such as elvitegravir, where bioavailability is limited and half-life is shortened by CYP3A-dependent metabolism. Elvitegravir is 6(3-Chloro-2-fluorobenzyl)-1-[(2S)-1-hydroxy-3-methylbutan-2-yl]-7-methoxy-4-oxo-1,4dihydro quinoline-3carboxylic acid were shown in figure 1D. Elvitegravir inhibits the strand transfer activity of HIV-1 integrase (integrase strand transfer inhibitor; INSTI), an HIV-1 encoded enzyme that is required for viral replication. Inhibition of integrase prevents the integration of HIV-1 DNA into host genomic DNA, blocking the formation of the HIV-1 provirus and propagation of the viral infection. Elvitegravir does not inhibit human topoisomerases I or $\mathrm{II}^{2}$.

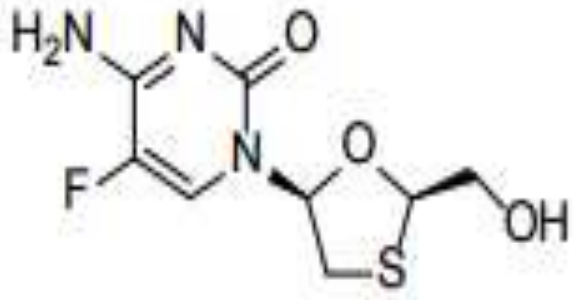

(A)

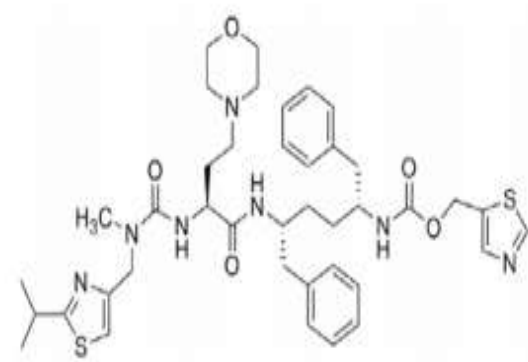

(C)<smiles>CC(C)OC(=O)OCOP(=O)(CO[C@H](C)Cn1cnc2c(N)ncnc21)OCOC(=O)OC(C)C</smiles>

(B)<smiles>CC=C(CO)n1cc(C(=O)O)c(=O)c2cc(Cc3cccc(Cl)c3F)c(OC)cc21</smiles>

(D)

Figure 1: Chemical structure of (A) Emtricitabine (B) Tenofovir Disoproxil Fumarate (C) Cobicistat (D) Elvitegravir

Literature survey reveals that many analytical methods are reported for determination of Emtricitabine, Tenofovir Disoproxil Fumarate, Cobicistat and Elvitegravir individually and with other combinations which includes high performance liquid chromatography (HPLC) ${ }^{3-18}$, liquid chromatography-mass spectrophotometry $(\mathrm{LC}-\mathrm{MS})^{19,20}$, UV-Spectrophotometry ${ }^{21}$ and high performance thin layer chromatography (HPTLC) ${ }^{22}$ methods. However, no method is reported for simultaneous estimation of Emtricitabine, Tenofovir Disoproxil Fumarate, Cobicistat and Elvitegravir in combined dosage form by Reversed Phase Ultra Performance Liquid Chromatography (UPLC) with forced degradation studies. The present study was aimed to develop a novel and validated Reversed Phase Ultra Performance Liquid Chromatography (UPLC) method for the simultaneous estimation of Emtricitabine, Tenofovir Disoproxil Fumarate, Cobicistat and Elvitegravir in bulk and pharmaceutical dosage form with forced degradation studies according to ICH guidelines ${ }^{23}$.

\section{Experimental}

\subsection{Chemicals and reagents}

Emtricitabine (API) and Tenofovir Disoproxil Fumarate (API) were obtained from Hetero Drugs Limited, Hyderabad, India. Cobicistat (API) and Elvitegravir (API) were obtained from Shilpa Medicare Limited, India. HPLC grade of Ammonium Acetate was obtained from Rankem Ltd., India and HPLC grade of Acetonitrile was obtained from Merck Specialities Private Limited, India. HPLC grade of Water and Ammonium hydroxide was obtained from Rankem Ltd., India. Stribild (Emtricitabine, Tenofovir Disoproxil Fumarate, Cobicistat and Elvitegravir) contains $200 \mathrm{mg}$ of Emtricitabine, $300 \mathrm{mg}$ of Tenofovir Disoproxil Fumarate, $150 \mathrm{mg}$ of Cobicistat and $150 \mathrm{mg}$ of Elvitegravir were kindly supplied by Gilead Sciences, Inc. 
A novel validated RP-UPLC-DAD method for the simultaneous estimation of Emtricitabine, ..

\subsection{Instrumentation}

The analysis was performed by using a chromatographic system from Waters Acquity UPLC system with PDA detector. The UPLC system was equipped with Empower 2 software. Semi-micro analytical balance (India), Ultrasonic bath sonicator (Frontline FS 4, Mumbai, India), Digital pH meter (Systronics model 802) and Whatmann filter paper No. 41 (Whatmann International Ltd., England) were used in the study.

\subsection{Selection of wavelength}

In simultaneous estimation of Emtricitabine, Tenofovir Disoproxil Fumarate, Cobicistat and Elvitegravir isosbestic wavelength is used. Standard stock solutions of Emtricitabine, Tenofovir Disoproxil Fumarate, Cobicistat and Elvitegravir were prepared by dissolving $200 \mathrm{mg}$ of Emtricitabine, $300 \mathrm{mg}$ of Tenofovir Disoproxil Fumarate, $150 \mathrm{mg}$ of Cobicistat and $150 \mathrm{mg}$ of Elvitegravir in $100 \mathrm{ml}$ of diluent into a 100 $\mathrm{ml}$ clean dry volumetric flask and the standard solutions was filtered through $0.45 \mu \mathrm{m}$ nylon membrane filter and degassed by sonicator to get the concentration of $2000 \mu \mathrm{g} / \mathrm{mL}$ of Emtricitabine, $3000 \mu \mathrm{g} / \mathrm{mL}$ of Tenofovir Disoproxil Fumarate, $1500 \mu \mathrm{g} / \mathrm{mL}$ of Cobicistat and $1500 \mu \mathrm{g} / \mathrm{mL}$ of Elvitegravir. From the above standard stock solution of $2000 \mu \mathrm{g} / \mathrm{mL}$ of Emtricitabine, $3000 \mu \mathrm{g} / \mathrm{mL}$ of Tenofovir Disoproxil Fumarate, $1500 \mu \mathrm{g} / \mathrm{mL} \mathrm{of}$ Cobicistat and $1500 \mu \mathrm{g} / \mathrm{mL}$ of Elvitegravir further pipette $1 \mathrm{~mL}$ and transferred into a $100 \mathrm{~mL}$ volumetric flask and dilute up to the mark with diluent to get the concentration of $20 \mu \mathrm{g} / \mathrm{mL}$ of Emtricitabine, $30 \mu \mathrm{g} / \mathrm{mL} \mathrm{of}$ Tenofovir Disoproxil Fumarate, $15 \mu \mathrm{g} / \mathrm{mL}$ of Cobicistat and $15 \mu \mathrm{g} / \mathrm{mL}$ of Elvitegravir. The wavelength of maximum absorption ( $\lambda \max$ ) of $20 \mu \mathrm{g} / \mathrm{mL}$ of Emtricitabine, $30 \mu \mathrm{g} / \mathrm{mL}$ of Tenofovir Disoproxil Fumarate, 15 $\mu \mathrm{g} / \mathrm{mL}$ of Cobicistat and $15 \mu \mathrm{g} / \mathrm{mL}$ of Elvitegravir were scanned using UV-Visible spectrophotometer within the wavelength region of $200-400 \mathrm{~nm}$ against mobile phase as blank. The isosbestic wavelength $(\lambda \max )$ was found to be $268 \mathrm{~nm}$ for the combination shown in figure 2 .

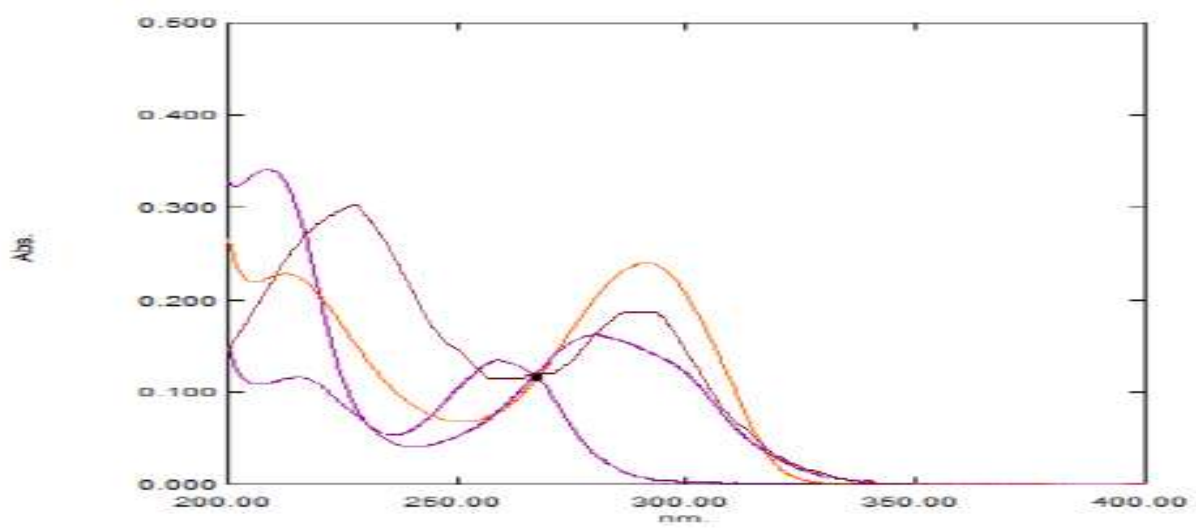

Figure 2: Isosbestic point of Emtricitabine, Tenofovir Disoproxil Fumarate, Cobicistat and Elvitegravir at 268 nm.

\subsection{Chromatographic conditions}

Emtricitabine, Tenofovir Disoproxil Fumarate, Cobicistat and Elvitegravir were analyzed in ACQUITY UPLC BEH $\mathrm{C}_{18}(100 \mathrm{~mm} \times 2.1 \mathrm{~mm}, 1.7 \mu \mathrm{m}$ particle size $)$ column for the chromatographic separation. The mobile phase was composed of 0.01M Ammonium acetate (pH adjusted to 7.5 with ammonium hydroxide) and Acetonitrile $(45: 55, \mathrm{v} / \mathrm{v})$. Filtered through $0.45 \mu \mathrm{m}$ nylon membrane filter under vacuum filtration and pumped at ambient temperature, at a flow rate of $0.25 \mathrm{~mL} / \mathrm{min}$ with UV detection wavelength at $268 \mathrm{~nm}$. Injection volume was $20 \mu \mathrm{L}$. The run time was $8 \mathrm{~min}$ and the retention time of Emtricitabine, Tenofovir Disoproxil Fumarate, Cobicistat and Elvitegravir was $0.904 \mathrm{~min}, 1.240 \mathrm{~min}, 2.615 \mathrm{~min}$ and $3.801 \mathrm{~min}$ with resolution of 4.05, 13.02 and 8.27 respectively.

Chromatographic Parameters:

$\begin{array}{ll}\text { Equipment } & : \text { Waters Acquity UPLC system with PDA detector } \\ \text { Column } & : \text { Acquity UPLC BEH C } 18 \text { (100 } \mathrm{mm} \times 2.1 \mathrm{~mm}, 1.7 \mu \mathrm{m} \text { particle size }) \\ \text { Flow rate } & : 0.25 \mathrm{~mL} / \mathrm{min} \\ \text { Wavelength } & : 268 \mathrm{~nm} \\ \text { Injection volume } & : 20 \mu \mathrm{L} \\ \text { Column oven } & : \text { Ambient } \\ \text { Run time } & : 8 \text { Minutes }\end{array}$




\subsection{Solutions and sample preparation}

\subsubsection{Preparation of Ammonium acetate buffer}

A $0.01 \mathrm{M}$ Ammonium acetate buffer was prepared by dissolving 0.77 gram of Ammonium acetate in $1000 \mathrm{~mL}$ of HPLC grade water and $\mathrm{pH}$ was adjusted to 7.5 with ammonium hydroxide. The buffer was filtered through $0.45 \mu \mathrm{m}$ nylon membrane filter to remove all fine particles and gases.

\subsubsection{Preparation of mobile phase}

The above prepared $0.01 \mathrm{M}$ Ammonium acetate buffer and Acetonitrile HPLC grade were mixed in the proportion of 45:55, v/v and was filtered through $0.45 \mu \mathrm{m}$ nylon membrane filter and degassed by sonication.

\subsubsection{Preparation of diluent}

Mobile phase was used as diluent.

\subsubsection{Preparation of standard stock solutions of Emtricitabine, Tenofovir Disoproxil Fumarate, Cobicistat and Elvitegravir}

Standard stock solutions of Emtricitabine, Tenofovir Disoproxil Fumarate, Cobicistat and Elvitegravir were prepared by dissolving $200 \mathrm{mg}$ of Emtricitabine, $300 \mathrm{mg}$ of Tenofovir Disoproxil Fumarate, $150 \mathrm{mg}$ of Cobicistat and $150 \mathrm{mg}$ of Elvitegravir in $100 \mathrm{~mL}$ of diluent into a $100 \mathrm{~mL}$ clean dry volumetric flask and the standard solutions was filtered through $0.45 \mu \mathrm{m}$ nylon membrane filter and degassed by sonicator to get the concentration of $2000 \mu \mathrm{g} / \mathrm{mL}$ of Emtricitabine, $3000 \mu \mathrm{g} / \mathrm{mL}$ of Tenofovir Disoproxil Fumarate, $1500 \mu \mathrm{g} / \mathrm{mL}$ of Cobicistat and $1500 \mu \mathrm{g} / \mathrm{mL}$ of Elvitegravir.

\subsubsection{Preparation of standard solutions of Emtricitabine, Tenofovir Disoproxil Fumarate, Cobicistat and Elvitegravir for assay}

From the above standard stock solution of $2000 \mu \mathrm{g} / \mathrm{mL}$ of Emtricitabine, $3000 \mu \mathrm{g} / \mathrm{mL}$ of Tenofovir Disoproxil Fumarate, $1500 \mu \mathrm{g} / \mathrm{mL}$ of Cobicistat and $1500 \mu \mathrm{g} / \mathrm{mL}$ of Elvitegravir further pipette $3 \mathrm{~mL}$ and transferred into a $100 \mathrm{~mL}$ volumetric flask and dilute up to the mark with diluent to get the concentration of 60 $\mu \mathrm{g} / \mathrm{mL}$ of Emtricitabine, $90 \mu \mathrm{g} / \mathrm{mL}$ of Tenofovir Disoproxil Fumarate, $45 \mu \mathrm{g} / \mathrm{mL}$ of Cobicistat and $45 \mu \mathrm{g} / \mathrm{mL}$ of Elvitegravir.

\subsubsection{Preparation of sample solutions of Emtricitabine, Tenofovir Disoproxil Fumarate, Cobicistat and Elvitegravir}

Stribild (Emtricitabine, Tenofovir Disoproxil Fumarate, Cobicistat and Elvitegravir) contains equivalent amount of $200 \mathrm{mg}$ of Emtricitabine, $300 \mathrm{mg}$ of Tenofovir Disoproxil Fumarate, $150 \mathrm{mg}$ of Cobicistat and $150 \mathrm{mg}$ of Elvitegravir were taken into $100 \mathrm{~mL}$ clean dry volumetric flask, diluent was added and sonicated to dissolve it completely and was filtered through $0.45 \mu \mathrm{m}$ nylon membrane filter and volume was made up to the mark with the same diluent. Further pipette out $3 \mathrm{~mL}$ from the above Emtricitabine, Tenofovir Disoproxil Fumarate, Cobicistat and Elvitegravir sample stock solution into a $100 \mathrm{~mL}$ volumetric flask and diluted up to the mark with diluent to get the concentration of $60 \mu \mathrm{g} / \mathrm{mL}$ of Emtricitabine, $90 \mu \mathrm{g} / \mathrm{mL}$ of Tenofovir Disoproxil Fumarate, $45 \mu \mathrm{g} / \mathrm{mL}$ of Cobicistat and $45 \mu \mathrm{g} / \mathrm{mL}$ of Elvitegravir. $20 \mu \mathrm{L}$ from standard and sample solution were injected into the chromatographic system and the peak areas were measured for Emtricitabine, Tenofovir Disoproxil Fumarate, Cobicistat and Elvitegravir which was shown in figure 3 and 4 and the assay \% was calculated by comparing the peak area of standard and sample chromatogram by using the formula given below and the assay results was shown in Table 1.

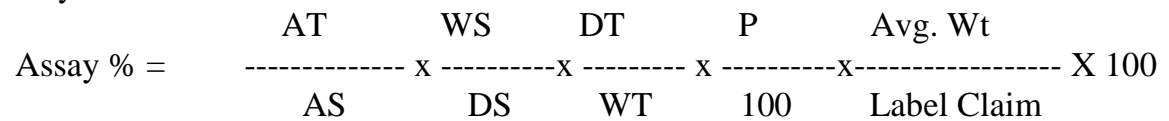

Where:

$\mathrm{AT}=$ Average peak area of sample preparation

$\mathrm{AS}=$ Average peak area of standard preparation

WS $=$ Weight of standard taken in $\mathrm{mg}$

WT=Weight of sample taken in $\mathrm{mg}$

$\mathrm{P}=$ Percentage purity of working standard

DS= Dilution factor for standard preparation

DT=Dilution factor for sample preparation 


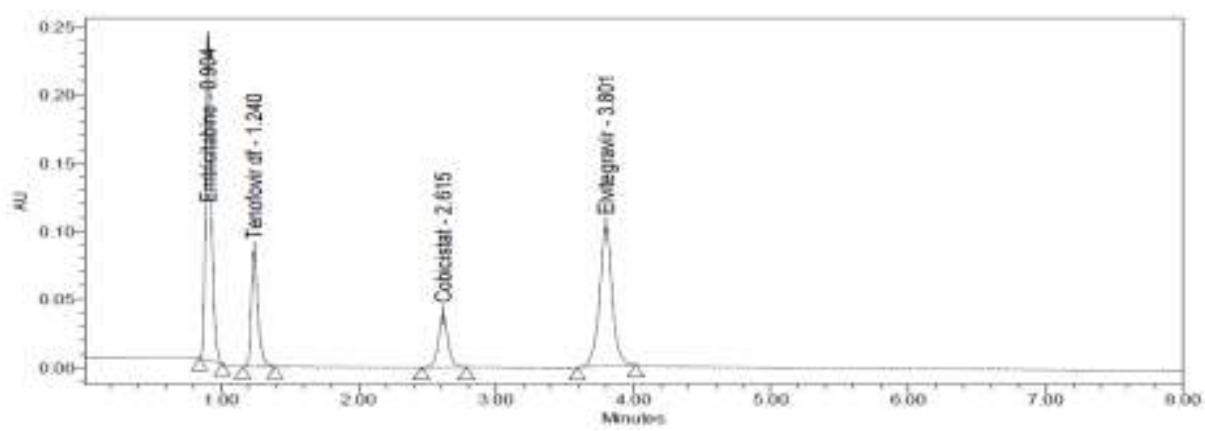

Figure 3: Standard chromatogram of Emtricitabine, Tenofovir Disoproxil Fumarate, Cobicistat and Elvitegravir.

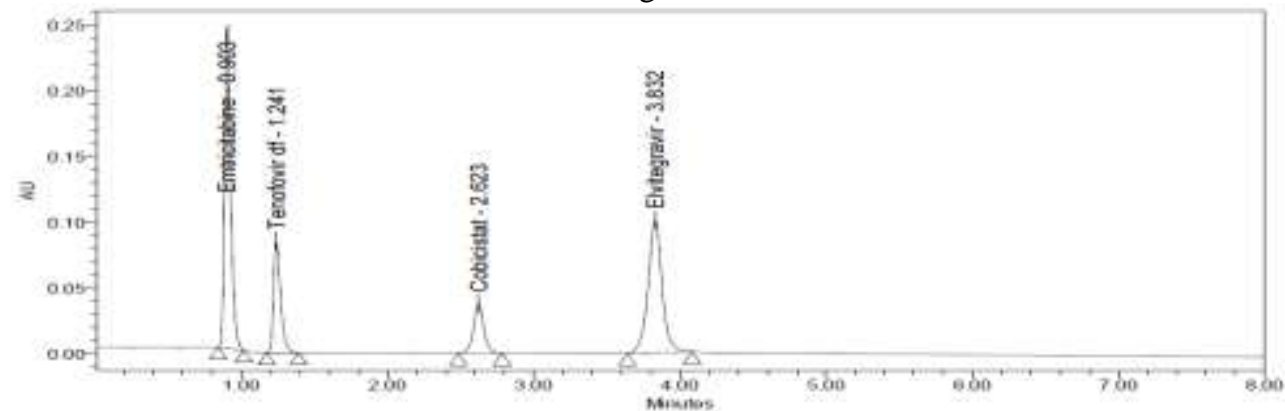

Figure 4: Sample chromatogram of Emtricitabine, Tenofovir Disoproxil Fumarate, Cobicistat and Elvitegravir.

Table 1. Assay of marketed formulation of Emtricitabine, Tenofovir Disoproxil Fumarate, Cobicistat and Elvitegravir.

\begin{tabular}{|l|l|l|l|}
\hline Drug & $\begin{array}{l}\text { Stribild } \\
\text { Label Claim }(\mathbf{m g})\end{array}$ & $\begin{array}{l}\text { Amount Found } \\
(\mathbf{m g})(\mathbf{n}=6)\end{array}$ & Label Claim \% \pm RSD \% (n=6) \\
\hline Emtricitabine & 200 & 200.51 & $100.26 \pm 0.4$ \\
\hline Tenofovir Disoproxil Fumarate & 300 & 298.66 & $99.55 \pm 0.23$ \\
\hline Cobicistat & 150 & 149.95 & $99.96 \pm 0.43$ \\
\hline Elvitegravir & 150 & 150.10 & $100.07 \pm 1.00$ \\
\hline
\end{tabular}

\subsection{Method validation}

The developed method for the simultaneous estimation of Emtricitabine, Tenofovir Disoproxil Fumarate, Cobicistat and Elvitegravir was validated as per the ICH guidelines for the parameters like system suitability, specificity, linearity, accuracy, precision, ruggedness, robustness, limit of detection (LOD) and limit of quantitation (LOQ) ${ }^{23}$.

\subsection{UPLC method development}

\section{Results}

To optimize the UPLC parameters, a number of commercially available UPLC columns and various mobile phases were evaluated for its chromatographic behavior of Emtricitabine, Tenofovir Disoproxil Fumarate, Cobicistat and Elvitegravir. A satisfactory separation and good peak symmetry for Emtricitabine, Tenofovir Disoproxil Fumarate, Cobicistat and Elvitegravir were obtained with ACQUITY UPLC BEH $\mathrm{C}_{18}$ (100 mm×2.1 mm, $1.7 \mu \mathrm{m}$ particle size) column, Waters ACQUITY UPLC system with PDA detector and mobile phase contained a mixture of $0.01 \mathrm{M}$ Ammonium acetate buffer ( $\mathrm{pH}$ adjusted to 7.5 with ammonium hydroxide) and Acetonitrile $(45: 55$, v/v) was delivered at a flow rate of $0.25 \mathrm{~mL} / \mathrm{min}$ to get better reproducibility and repeatability. Quantification was achieved with PDA detection at $268 \mathrm{~nm}$ based on peak area.

\subsection{UPLC method validation}

\subsubsection{System suitability}

At first the UPLC system was optimized as per the chromatographic conditions. One blank followed by six replicates of a single calibration standard solution of $60 \mu \mathrm{g} / \mathrm{mL}$ of Emtricitabine, $90 \mu \mathrm{g} / \mathrm{mL}$ of Tenofovir Disoproxil Fumarate, $45 \mu \mathrm{g} / \mathrm{mL}$ of Cobicistat and $45 \mu \mathrm{g} / \mathrm{mL}$ of Elvitegravir was injected to check the system suitability. To ascertain the system suitability for the proposed method, the parameters such as retention time, theoretical plates, peak asymmetry and resolution were taken and results were presented in Table 2 . 
A novel validated RP-UPLC-DAD method for the simultaneous estimation of Emtricitabine, ..

Table 2. System suitability parameters for Emtricitabine, Tenofovir Disoproxil Fumarate, Cobicistat and Elvitegravir.

\begin{tabular}{|l|l|l|l|l|}
\hline $\begin{array}{l}\text { Parameter } \\
(\mathbf{n = 6})\end{array}$ & Emtricitabine & $\begin{array}{l}\text { Tenofovir Disoproxil } \\
\text { Fumarate }\end{array}$ & Cobicistat & Elvitegravir \\
\hline Retention Time (Minutes) & 0.904 & 1.240 & 2.615 & 3.801 \\
\hline Theoretical plates & 2117 & 3261 & 7064 & 8757 \\
\hline Tailing factor & 1.41 & 1.46 & 1.02 & 0.98 \\
\hline Resolution & & 4.05 & 13.02 & 8.27 \\
\hline
\end{tabular}

\subsubsection{Specificity}

The effect of excipients and other additives usually present in the combined dosage form of Emtricitabine, Tenofovir Disoproxil Fumarate, Cobicistat and Elvitegravir in the determination under optimum conditions was investigated. The specificity of the UPLC method was established by injecting the blank and placebo solution into the UPLC system. The representative chromatogram of blank and placebo was shown in figure 5 and 6.

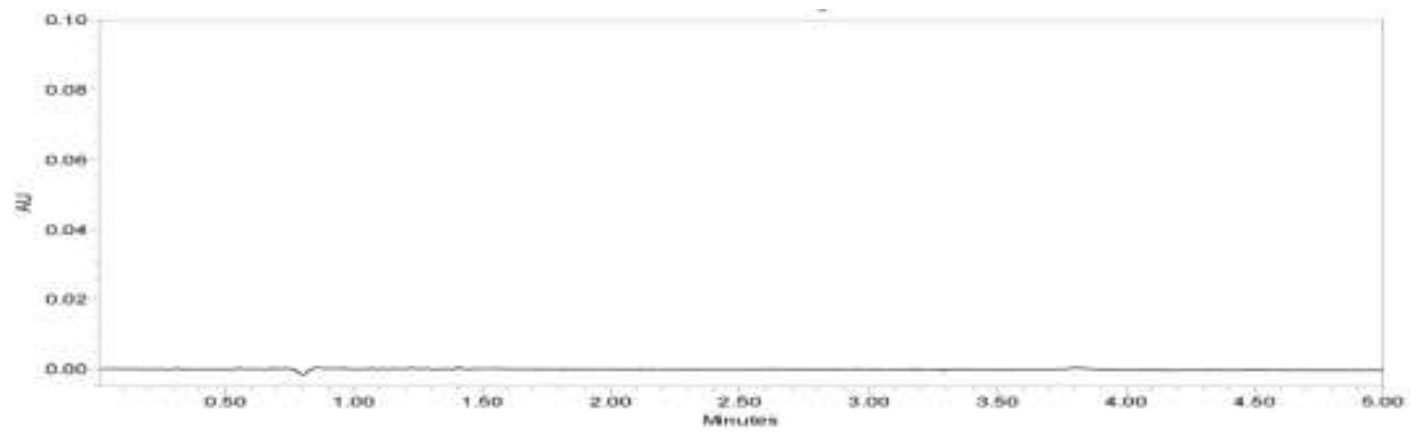

Figure 5: Chromatogram of blank.

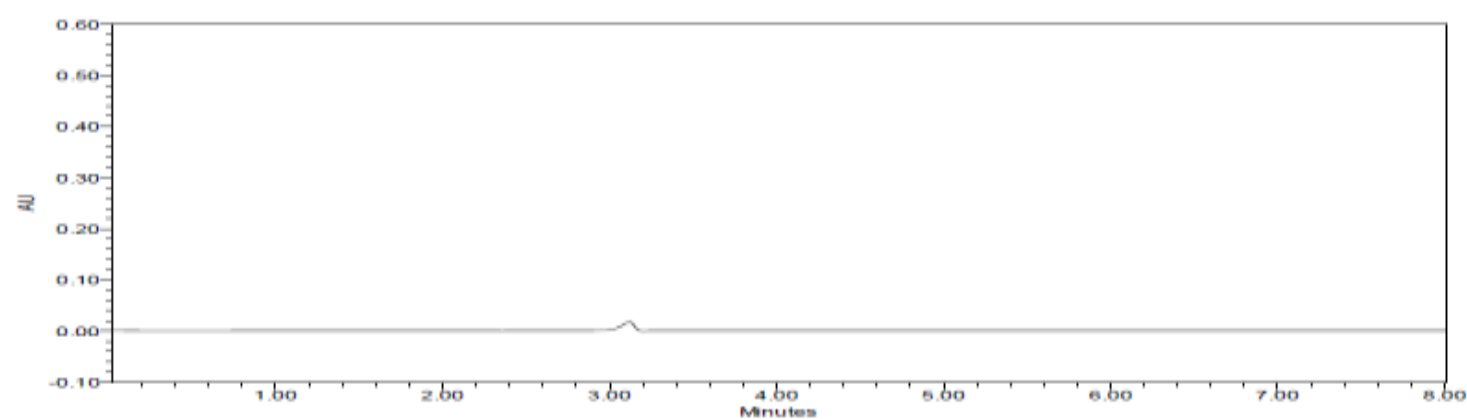

Figure 6: Chromatogram of placebo.

\subsubsection{Linearity and range for Emtricitabine, Tenofovir Disoproxil Fumarate, Cobicistat and Elvitegravir}

Aliquots of $0.1,0.2,0.3,0.4$ and $0.5 \mathrm{~mL}$ of mixed standard working solutions of Emtricitabine, Tenofovir Disoproxil Fumarate, Cobicistat and Elvitegravir was pipette out from the standard stock solution of $2000 \mu \mathrm{g} / \mathrm{mL}$ of Emtricitabine, $3000 \mu \mathrm{g} / \mathrm{mL}$ of Tenofovir Disoproxil Fumarate, $1500 \mu \mathrm{g} / \mathrm{mL}$ of Cobicistat and $1500 \mu \mathrm{g} / \mathrm{mL}$ of Elvitegravir and transferred into a series of $10 \mathrm{ml}$ clean dry volumetric flask and make volume up to the mark with the same diluent to get the concentration of $20,40,60,80$ and $100 \mu \mathrm{g} / \mathrm{mL}$ of Emtricitabine, 30, 60, 90, 120 and $150 \mu \mathrm{g} / \mathrm{mL}$ of Tenofovir Disoproxil Fumarate, 15, 30, 45, 60 and $75 \mu \mathrm{g} / \mathrm{mL}$ of Cobicistat and $15,30,45,60$ and $75 \mu \mathrm{g} / \mathrm{mL}$ of Elvitegravir. The calibration standard solutions of Emtricitabine, Tenofovir Disoproxil Fumarate, Cobicistat and Elvitegravir were injected using a $20 \mu \mathrm{L}$ Hamilton Rheodyne injector and the chromatograms were recorded at $268 \mathrm{~nm}$ and a calibration graph was obtained by plotting peak area versus concentration of Emtricitabine, Tenofovir Disoproxil Fumarate, Cobicistat and Elvitegravir respectively. The linearity data is presented in figure 7 and Table 3. Acceptance Criteria: Correlation coefficient should be not less than 0.999 . 


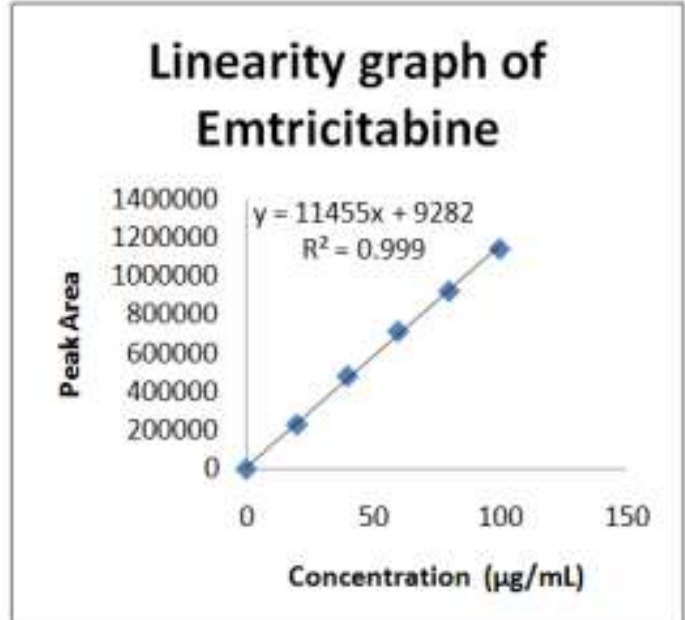

(A)

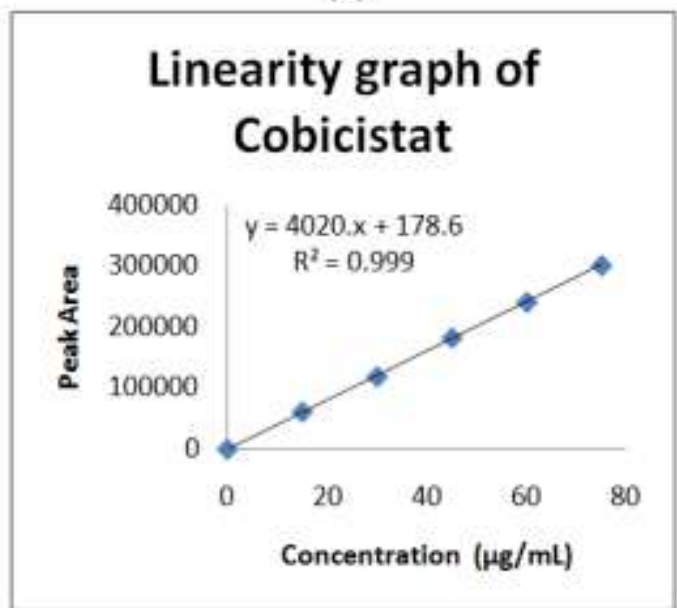

(C)

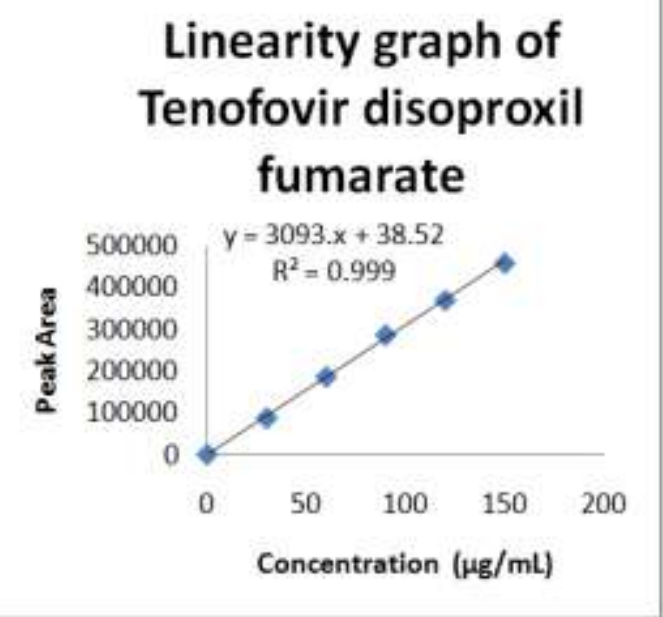

(B)

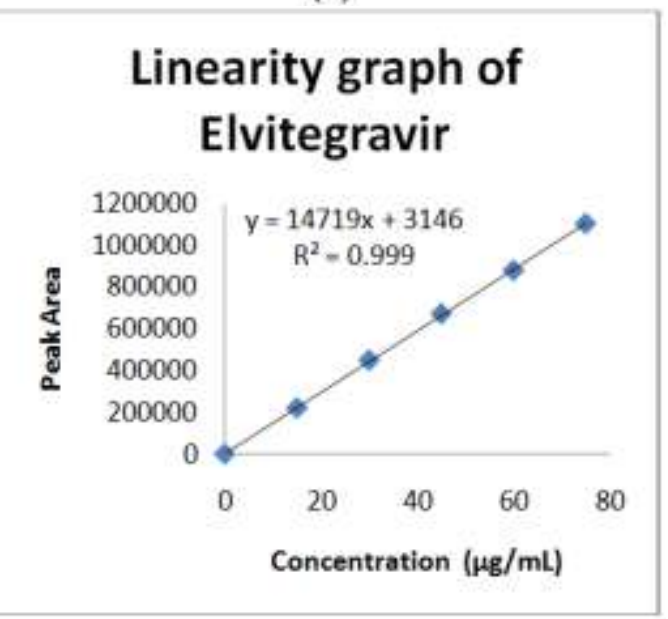

(D)

Figure 7: Linearity graph of (A) Emtricitabine (B) Tenofovir Disoproxil Fumarate (C) Cobicistat (D) Elvitegravir

Table 3. Linearity data for Emtricitabine, Tenofovir Disoproxil Fumarate, Cobicistat and Elvitegravir.

\begin{tabular}{|l|l|l|l|}
\hline Linearity of Emtricitabine & \multicolumn{2}{l|}{ Linearity of Tenofovir Disoproxil Fumarate } \\
\hline Concentration $(\mu \mathrm{g} / \mathrm{mL})$ & Peak Area & Concentration $(\mu \mathrm{g} / \mathrm{mL})$ & Peak Area \\
\hline 20 & 230537 & 30 & 87796 \\
\hline 40 & 482835 & 60 & 186776 \\
\hline 60 & 713994 & 90 & 287190 \\
\hline 80 & 922636 & 120 & 370559 \\
\hline 100 & 1142222 & 150 & 459815 \\
\hline Linearity of Cobicistat & \multicolumn{3}{|l|}{ Linearity of Elvitegravir } \\
\hline Concentration $(\mu \mathrm{g} / \mathrm{mL})$ & Peak Area & Concentration $(\mu \mathrm{g} / \mathrm{mL})$ & Peak Area \\
\hline 15 & 61237 & 15 & 221116 \\
\hline 30 & 118996 & 30 & 450161 \\
\hline 45 & 182791 & 45 & 673388 \\
\hline 60 & 241282 & 60 & 881031 \\
\hline 75 & 301356 & 75 & 1104853 \\
\hline
\end{tabular}

\subsubsection{Accuracy studies for Emtricitabine, Tenofovir Disoproxil Fumarate, Cobicistat and Elvitegravir}

The accuracy of the method was determined by calculating recovery of Emtricitabine, Tenofovir Disoproxil Fumarate, Cobicistat and Elvitegravir by the method of standard addition. Known amount of standard solution of Emtricitabine, Tenofovir Disoproxil Fumarate, Cobicistat and Elvitegravir at 50\%, 100\% and $150 \%$ was added to a pre quantified sample solution and injected into the UPLC system. The mean percentage recovery of Emtricitabine, Tenofovir Disoproxil Fumarate, Cobicistat and Elvitegravir at each level was calculated and the results were presented in Table 4. 
A novel validated RP-UPLC-DAD method for the simultaneous estimation of Emtricitabine, ..

\subsubsection{Preparation of pre quantified sample solution for accuracy studies}

Stribild (Emtricitabine, Tenofovir Disoproxil Fumarate, Cobicistat and Elvitegravir) contains equivalent amount of $200 \mathrm{mg}$ of Emtricitabine, $300 \mathrm{mg}$ of Tenofovir Disoproxil Fumarate, $150 \mathrm{mg}$ of Cobicistat and $150 \mathrm{mg}$ of Elvitegravir were taken into $100 \mathrm{~mL}$ clean dry volumetric flask, diluent was added and sonicated to dissolve it completely and was filtered through $0.45 \mu \mathrm{m}$ nylon membrane filter and volume was made up to the mark with the same diluent. Further pipette out $0.2 \mathrm{~mL}$ from the above Emtricitabine, Tenofovir Disoproxil Fumarate, Cobicistat and Elvitegravir sample stock solution into a $10 \mathrm{~mL}$ volumetric flask and diluted up to the mark with diluent to get the concentration of $40 \mu \mathrm{g} / \mathrm{mL}$ of Emtricitabine, $60 \mu \mathrm{g} / \mathrm{mL}$ of Tenofovir Disoproxil Fumarate, $30 \mu \mathrm{g} / \mathrm{mL}$ of Cobicistat and $30 \mu \mathrm{g} / \mathrm{mL}$ of Elvitegravir.

\subsubsection{Preparation of standard solution of Emtricitabine, Tenofovir Disoproxil Fumarate, Cobicistat and Elvitegravir for accuracy studies}

Standard stock solutions of Emtricitabine, Tenofovir Disoproxil Fumarate, Cobicistat and Elvitegravir were prepared by dissolving $200 \mathrm{mg}$ of Emtricitabine, $300 \mathrm{mg}$ of Tenofovir Disoproxil Fumarate, $150 \mathrm{mg}$ of Cobicistat and $150 \mathrm{mg}$ of Elvitegravir in $100 \mathrm{~mL}$ of diluent into a $100 \mathrm{~mL}$ clean dry volumetric flask and the standard solutions was filtered through $0.45 \mu \mathrm{m}$ nylon membrane filter and degassed by sonicator to get the concentration of $2000 \mu \mathrm{g} / \mathrm{mL}$ of Emtricitabine, $3000 \mu \mathrm{g} / \mathrm{mL}$ of Tenofovir Disoproxil Fumarate, $1500 \mu \mathrm{g} / \mathrm{mL}$ of Cobicistat and $1500 \mu \mathrm{g} / \mathrm{mL}$ of Elvitegravir.

\section{a.) Preparation of 50\% standard solution}

From the standard stock solution of $2000 \mu \mathrm{g} / \mathrm{mL}$ of Emtricitabine, $3000 \mu \mathrm{g} / \mathrm{mL}$ of Tenofovir Disoproxil Fumarate, $1500 \mu \mathrm{g} / \mathrm{mL}$ of Cobicistat and $1500 \mu \mathrm{g} / \mathrm{mL}$ of Elvitegravir further pipette $0.1 \mathrm{~mL}$ and transferred into a $10 \mathrm{~mL}$ volumetric flask and dilute up to the mark with diluent to get the concentration of 20 $\mu \mathrm{g} / \mathrm{mL}$ of Emtricitabine, $30 \mu \mathrm{g} / \mathrm{mL}$ of Tenofovir Disoproxil Fumarate, $15 \mu \mathrm{g} / \mathrm{mL}$ of Cobicistat and $15 \mu \mathrm{g} / \mathrm{mL}$ of Elvitegravir.

\section{b.) Preparation of $100 \%$ standard solution}

From the standard stock solution of $2000 \mu \mathrm{g} / \mathrm{mL}$ of Emtricitabine, $3000 \mu \mathrm{g} / \mathrm{mL}$ of Tenofovir Disoproxil Fumarate, $1500 \mu \mathrm{g} / \mathrm{mL}$ of Cobicistat and $1500 \mu \mathrm{g} / \mathrm{mL}$ of Elvitegravir further pipette $0.2 \mathrm{~mL}$ and transferred into a $10 \mathrm{~mL}$ volumetric flask and dilute up to the mark with diluent to get the concentration of 40 $\mu \mathrm{g} / \mathrm{mL}$ of Emtricitabine, $60 \mu \mathrm{g} / \mathrm{mL}$ of Tenofovir Disoproxil Fumarate, $30 \mu \mathrm{g} / \mathrm{mL}$ of Cobicistat and $30 \mu \mathrm{g} / \mathrm{mL}$ of Elvitegravir.

\section{c.) Preparation of $150 \%$ standard solution}

From the standard stock solution of $2000 \mu \mathrm{g} / \mathrm{mL}$ of Emtricitabine, $3000 \mu \mathrm{g} / \mathrm{mL}$ of Tenofovir Disoproxil Fumarate, $1500 \mu \mathrm{g} / \mathrm{mL}$ of Cobicistat and $1500 \mu \mathrm{g} / \mathrm{mL}$ of Elvitegravir further pipette $0.3 \mathrm{~mL}$ and transferred into a $10 \mathrm{~mL}$ volumetric flask and dilute up to the mark with diluent to get the concentration of 60 $\mu \mathrm{g} / \mathrm{mL}$ of Emtricitabine, $90 \mu \mathrm{g} / \mathrm{mL}$ of Tenofovir Disoproxil Fumarate, $45 \mu \mathrm{g} / \mathrm{mL}$ of Cobicistat and $45 \mu \mathrm{g} / \mathrm{mL}$ of Elvitegravir. Acceptance Criteria: The Recovery \% for each level should be between 98.0 to $102.0 \%$.

Table 4. Recovery studies of Emtricitabine, Tenofovir DF, Cobicistat and Elvitegravir.

\begin{tabular}{|c|c|c|c|c|}
\hline \multicolumn{5}{|c|}{ Recovery study data of Emtricitabine } \\
\hline Sample name & Amount added $(\mu \mathrm{g} / \mathrm{mL})$ & Amount found $(\mu \mathrm{g} / \mathrm{mL})$ & Recovery \% & Statistical Analysis \\
\hline $\mathrm{S}_{1}: 50 \%$ & 20 & 19.97 & 99.86 & \multirow{3}{*}{$\begin{array}{l}\text { Mean }=99.83 \%(n=3) \\
\text { S.D }=0.22 \\
\text { RSD } \%=0.22\end{array}$} \\
\hline $\mathbf{S}_{2}: 50 \%$ & 20 & 19.92 & 99.60 & \\
\hline $\mathrm{S}_{3}: 50 \%$ & 20 & 20.01 & 100.03 & \\
\hline $\mathrm{S}_{4}: 100 \%$ & 40 & 40.02 & 100.04 & \multirow{3}{*}{$\begin{array}{l}\text { Mean }=99.96 \%(n=3) \\
\text { S.D }=0.12 \\
\text { RSD } \%=0.12\end{array}$} \\
\hline $\mathrm{S}_{5}: 100 \%$ & 40 & 39.93 & 99.82 & \\
\hline$S_{6}: 100 \%$ & 40 & 40.01 & 100.02 & \\
\hline $\mathrm{S}_{7}: 150 \%$ & 60 & 59.77 & 99.61 & \multirow{3}{*}{$\begin{array}{l}\text { Mean=99.55\%(n=3) } \\
\text { S.D=0.15 } \\
\text { RSD \% }=0.15\end{array}$} \\
\hline $\mathrm{S}_{8}: 150 \%$ & 60 & 59.63 & 99.38 & \\
\hline $\mathrm{S}_{9}: 150 \%$ & 60 & 59.79 & 99.65 & \\
\hline \multicolumn{5}{|c|}{ Recovery study data of Tenofovir Disoproxil Fumarate } \\
\hline Sample name & Amount added $(\mu \mathrm{g} / \mathrm{mL})$ & Amount found $(\mu \mathrm{g} / \mathrm{mL})$ & Recovery \% & Statistical Analysis \\
\hline $\mathrm{S}_{1}: \mathbf{5 0 \%}$ & 30 & 30.05 & 100.18 & \multirow{3}{*}{$\begin{array}{l}\text { Mean }=100.04 \%(n=3) \\
\text { S.D }=0.22 \\
\text { RSD } \%=0.22\end{array}$} \\
\hline $\mathrm{S}_{2}: 50 \%$ & 30 & 29.93 & 99.78 & \\
\hline $\mathrm{S}_{3}: 50 \%$ & 30 & 30.05 & 100.15 & \\
\hline$S_{4}: 100 \%$ & 60 & 60.13 & 100.21 & \multirow{3}{*}{$\begin{array}{l}\text { Mean }=100.07 \%(n=3) \\
\text { S.D }=0.14 \\
\text { RSD } \%=0.14\end{array}$} \\
\hline $\mathrm{S}_{5}: 100 \%$ & 60 & 59.96 & 99.93 & \\
\hline $\mathrm{S}_{6}: 100 \%$ & 60 & 60.03 & 100.05 & \\
\hline$S_{7}: 150 \%$ & 90 & 90.04 & 100.04 & \multirow{3}{*}{$\begin{array}{l}\text { Mean }=100.04 \%(n=3) \\
\text { S.D }=0.03 \\
\text { RSD } \%=0.03\end{array}$} \\
\hline $\mathrm{S}_{8}: 150 \%$ & 90 & 90.06 & 100.07 & \\
\hline $\mathrm{S}_{9}: 150 \%$ & 90 & 90.01 & 100.02 & \\
\hline
\end{tabular}


A novel validated RP-UPLC-DAD method for the simultaneous estimation of Emtricitabine, ..

\begin{tabular}{|c|c|c|c|c|}
\hline \multicolumn{5}{|c|}{ Recovery study data of Cobicistat } \\
\hline Sample name & Amount added $(\mu \mathrm{g} / \mathrm{mL})$ & Amount found $(\mu \mathrm{g} / \mathrm{mL})$ & Recovery $\%$ & Statistical Analysis \\
\hline $\mathrm{S}_{1}: 50 \%$ & 15 & 15.05 & 100.34 & \multirow{3}{*}{$\begin{array}{l}\text { Mean }=100.09 \%(\mathrm{n}=3) \\
\text { S.D }=0.24 \\
\text { RSD } \%=0.24\end{array}$} \\
\hline $\mathbf{S}_{2}: 50 \%$ & 15 & 14.98 & 99.85 & \\
\hline $\mathbf{S}_{3}: 50 \%$ & 15 & 15.01 & 100.08 & \\
\hline$S_{4}: 100 \%$ & 30 & 30.07 & 100.22 & \multirow{3}{*}{$\begin{array}{l}\text { Mean }=99.86 \%(n=3) \\
\text { S.D }=0.33 \\
\text { RSD } \%=0.33\end{array}$} \\
\hline $\mathrm{S}_{5}: 100 \%$ & 30 & 29.87 & 99.57 & \\
\hline $\mathrm{S}_{6}: 100 \%$ & 30 & 29.94 & 99.79 & \\
\hline $\mathrm{S}_{7}: 150 \%$ & 45 & 45.06 & 100.13 & \multirow{3}{*}{$\begin{array}{l}\text { Mean }=99.93 \%(n=3) \\
\text { S.D }=0.28 \\
\text { RSD } \%=0.28\end{array}$} \\
\hline $\mathrm{S}_{8}: 150 \%$ & 45 & 45.02 & 100.03 & \\
\hline$S_{9}: 150 \%$ & 45 & 44.82 & 99.61 & \\
\hline \multicolumn{5}{|c|}{ Recovery study data of Elvitegravir } \\
\hline Sample name & Amount added $(\mu \mathrm{g} / \mathrm{mL})$ & Amount found $(\mu \mathrm{g} / \mathrm{mL})$ & Recovery $\%$ & Statistical Analysis \\
\hline $\mathrm{S}_{1}: 50 \%$ & 15 & 14.98 & 99.89 & \multirow{3}{*}{$\begin{array}{l}\text { Mean }=100.06 \%(\mathrm{n}=3) \\
\text { S.D }=0.15 \\
\text { RSD } \%=0.15\end{array}$} \\
\hline $\mathrm{S}_{2}: 50 \%$ & 15 & 15.03 & 100.19 & \\
\hline $\mathrm{S}_{3}: 50 \%$ & 15 & 15.01 & 100.09 & \\
\hline$S_{4}: 100 \%$ & 30 & 30.01 & 100.05 & \multirow{3}{*}{$\begin{array}{l}\text { Mean }=99.95 \%(n=3) \\
\text { S.D }=0.25 \\
\text { RSD } \%=0.25\end{array}$} \\
\hline$S_{5}: 100 \%$ & 30 & 30.04 & 100.14 & \\
\hline $\mathrm{S}_{6}: 100 \%$ & 30 & 29.90 & 99.67 & \\
\hline$S_{7}: 150 \%$ & 45 & 44.98 & 99.96 & \multirow{3}{*}{$\begin{array}{l}\text { Mean }=100.19 \%(\mathrm{n}=3) \\
\text { S.D }=0.24 \\
\text { RSD } \%=0.24\end{array}$} \\
\hline $\mathrm{S}_{8}: 150 \%$ & 45 & 45.20 & 100.44 & \\
\hline$S_{9}: 150 \%$ & 45 & 45.07 & 100.16 & \\
\hline
\end{tabular}

\subsubsection{Precision studies for Emtricitabine, Tenofovir Disoproxil Fumarate, Cobicistat and Elvitegravir 3.2.5.1 Method precision (Repeatability)}

Stribild (Emtricitabine, Tenofovir Disoproxil Fumarate, Cobicistat and Elvitegravir) contains equivalent amount of $200 \mathrm{mg}$ of Emtricitabine, $300 \mathrm{mg}$ of Tenofovir Disoproxil Fumarate, $150 \mathrm{mg}$ of Cobicistat and $150 \mathrm{mg}$ of Elvitegravir were taken into $100 \mathrm{~mL}$ clean dry volumetric flask, diluent was added and sonicated to dissolve it completely and was filtered through $0.45 \mu \mathrm{m}$ nylon membrane filter and volume was made up to the mark with the same diluent. Further pipette out $3 \mathrm{~mL}$ from the above Emtricitabine, Tenofovir Disoproxil Fumarate, Cobicistat and Elvitegravir sample stock solution into a $100 \mathrm{~mL}$ volumetric flask and diluted up to the mark with diluent to get the concentration of $60 \mu \mathrm{g} / \mathrm{mL}$ of Emtricitabine, $90 \mu \mathrm{g} / \mathrm{mL}$ of Tenofovir Disoproxil Fumarate, $45 \mu \mathrm{g} / \mathrm{mL}$ of Cobicistat and $45 \mu \mathrm{g} / \mathrm{mL}$ of Elvitegravir. A homogenous sample of a single batch is analyzed six times and was checked whether the method is giving consistent results. The RSD \% for the assay of six replicate injections was calculated as mentioned in Table 5. Acceptance Criteria: The RSD \% for the assay of six sample injections should not be more than $2 \%$.

Table 5. Method precision data for Emtricitabine, Tenofovir Disoproxil Fumarate, Cobicistat and Elvitegravir.

\begin{tabular}{|c|c|c|c|c|c|c|c|c|}
\hline \multicolumn{5}{|c|}{ Emtricitabine } & \multicolumn{4}{|c|}{ Tenofovir Disoproxil Fumarate } \\
\hline S.No. & $\begin{array}{l}\text { Concentration } \\
(\mu \mathrm{g} / \mathrm{mL})\end{array}$ & $\begin{array}{l}\text { Retention } \\
\text { time (min) }\end{array}$ & $\begin{array}{l}\text { Peak } \\
\text { Area }\end{array}$ & Assay \% & $\begin{array}{l}\text { Concentration } \\
(\mu \mathrm{g} / \mathrm{mL})\end{array}$ & $\begin{array}{l}\text { Retention } \\
\text { time (min) }\end{array}$ & $\begin{array}{l}\text { Peak } \\
\text { Area }\end{array}$ & Assay \% \\
\hline 1 & 60 & 0.926 & 726133 & 100.21 & 90 & 1.285 & 289566 & 99.77 \\
\hline 2 & 60 & 0.924 & 723732 & 99.88 & 90 & 1.283 & 292125 & 100.65 \\
\hline 3 & 60 & 0.921 & 722779 & 99.75 & 90 & 1.281 & 288450 & 99.39 \\
\hline 4 & 60 & 0.923 & 723780 & 99.89 & 90 & 1.283 & 288621 & 99.44 \\
\hline 5 & 60 & 0.919 & 723430 & 99.84 & 90 & 1.278 & 292676 & 100.84 \\
\hline 6 & 60 & 0.923 & 722593 & 99.72 & 90 & 1.279 & 288870 & 99.53 \\
\hline \multicolumn{2}{|c|}{ Average } & 0.923 & 723741 & 99.88 & Average & 1.282 & 290051 & 99.94 \\
\hline \multicolumn{2}{|c|}{ SD } & 0.002422 & 1269.91 & 0.18 & SD & 0.002665 & 1867.09 & 0.64 \\
\hline RSD & & 0.26 & 0.18 & 0.18 & RSD \% & 0.21 & 0.64 & 0.64 \\
\hline \multicolumn{5}{|c|}{ Cobicistat } & \multicolumn{4}{|l|}{ Elvitegravir } \\
\hline S.No. & $\begin{array}{l}\text { Concentration } \\
(\mu \mathrm{g} / \mathrm{mL})\end{array}$ & $\begin{array}{l}\text { Retention } \\
\text { time (min) }\end{array}$ & $\begin{array}{l}\text { Peak } \\
\text { Area } \\
\end{array}$ & Assay \% & $\begin{array}{l}\text { Concentration } \\
(\mu \mathrm{g} / \mathrm{mL})\end{array}$ & $\begin{array}{l}\text { Retention } \\
\text { time (min) }\end{array}$ & $\begin{array}{l}\text { Peak } \\
\text { Area } \\
\end{array}$ & Assay \% \\
\hline 1 & 45 & 2.816 & 187393 & 99.20 & 45 & 4.146 & 692879 & 100.62 \\
\hline 2 & 45 & 2.808 & 188609 & 99.84 & 45 & 4.142 & 687276 & 99.80 \\
\hline 3 & 45 & 2.807 & 188603 & 99.84 & 45 & 4.139 & 696404 & 101.13 \\
\hline 4 & 45 & 2.809 & 187952 & 99.49 & 45 & 4.145 & 684272 & 99.37 \\
\hline 5 & 45 & 2.802 & 189421 & 100.27 & 45 & 4.139 & 686231 & 99.65 \\
\hline 6 & 45 & 2.794 & 189247 & 100.18 & 45 & 4.135 & 682101 & 99.05 \\
\hline \multicolumn{2}{|c|}{ Average } & 2.806 & 188538 & 99.80 & Average & 4.141 & 688194 & 99.94 \\
\hline \multirow{2}{*}{\multicolumn{2}{|c|}{ SD }} & 0.007403 & 767.60 & 0.41 & SD & 0.004147 & 5413.98 & 0.79 \\
\hline & & 0.26 & 0.41 & 0.41 & RSD \% & 0.1 & 0.79 & 0.79 \\
\hline
\end{tabular}

\subsubsection{System precision}

The system precision was carried out to ensure that the analytical system is working properly. The standard preparation concentration of $60 \mu \mathrm{g} / \mathrm{mL}$ of Emtricitabine, $90 \mu \mathrm{g} / \mathrm{mL}$ of Tenofovir Disoproxil Fumarate, 
A novel validated RP-UPLC-DAD method for the simultaneous estimation of Emtricitabine, ..

$45 \mu \mathrm{g} / \mathrm{mL}$ of Cobicistat and $45 \mu \mathrm{g} / \mathrm{mL}$ of Elvitegravir was injected six times into the UPLC system and the RSD $\%$ for the area of six replicate injections was calculated as mentioned in Table 6. Acceptance Criteria: The RSD $\%$ for the peak area of six standard injections should not be more than $2 \%$.

Table 6. System precision data for Emtricitabine, Tenofovir Disoproxil Fumarate, Cobicistat and Elvitegravir.

\begin{tabular}{|c|c|c|c|c|c|c|}
\hline \multicolumn{4}{|c|}{ Emtricitabine } & \multicolumn{3}{|c|}{ Tenofovir Disoproxil Fumarate } \\
\hline S.No. & $\begin{array}{l}\text { Conc. } \\
(\mu \mathrm{g} / \mathrm{mL})\end{array}$ & $\begin{array}{l}\text { Retention } \\
\text { Time (min) }\end{array}$ & Peak Area & $\begin{array}{l}\text { Conc. } \\
(\mu \mathrm{g} / \mathrm{mL})\end{array}$ & $\begin{array}{l}\text { Retention } \\
\text { time (min) }\end{array}$ & Peak Area \\
\hline 1 & 60 & 0.926 & 714733 & 90 & 1.285 & 288383 \\
\hline 2 & 60 & 0.913 & 705793 & 90 & 1.268 & 282989 \\
\hline 3 & 60 & 0.919 & 710858 & 90 & 1.278 & 288710 \\
\hline 4 & 60 & 0.919 & 711211 & 90 & 1.278 & 288776 \\
\hline 5 & 60 & 0.926 & 710008 & 90 & 1.286 & 288289 \\
\hline 6 & 60 & 0.921 & 704761 & 90 & 1.281 & 284155 \\
\hline \multicolumn{2}{|c|}{ Average } & 0.921 & 709561 & Average & 1.279 & 286884 \\
\hline \multicolumn{2}{|c|}{ SD } & 0.004926 & 3703.8338 & SD & 0.006501 & 2598.208 \\
\hline RSD & & 0.54 & 0.52 & RSD \% & 0.51 & 0.91 \\
\hline \multicolumn{4}{|c|}{ Cobicistat } & \multicolumn{3}{|c|}{ Elvitegravir } \\
\hline S.No. & $\begin{array}{l}\text { Conc. } \\
(\mu \mathrm{g} / \mathrm{mL})\end{array}$ & $\begin{array}{l}\text { Retention } \\
\text { Time (min) }\end{array}$ & Peak Area & $\begin{array}{l}\text { Conc. } \\
(\mu \mathrm{g} / \mathrm{mL})\end{array}$ & $\begin{array}{l}\text { Retention } \\
\text { time (min) }\end{array}$ & Peak Area \\
\hline 1 & 45 & 2.816 & 188313 & 45 & 3.922 & 679833 \\
\hline 2 & 45 & 2.751 & 186597 & 45 & 4.046 & 676216 \\
\hline 3 & 45 & 2.802 & 186341 & 45 & 3.930 & 669763 \\
\hline 4 & 45 & 2.802 & 186517 & 45 & 3.801 & 674183 \\
\hline 5 & 45 & 2.828 & 187017 & 45 & 4.152 & 660703 \\
\hline 6 & 45 & 2.807 & 183515 & 45 & 3.792 & 672501 \\
\hline \multicolumn{2}{|c|}{ Average } & 2.801 & 186383 & Average & 4.127 & 672200 \\
\hline \multicolumn{2}{|c|}{ SD } & 0.026427 & 1576 & SD & 0.039947 & 6581 \\
\hline \multicolumn{2}{|c|}{ RSD \% } & 0.94 & 0.85 & RSD \% & 1.0 & 0.98 \\
\hline
\end{tabular}

\subsubsection{Intermediate precision/ruggedness}

The intermediate precision (also known as Ruggedness) of the method was evaluated by performing precision on different laboratories by different analysts and different days. The sample preparation concentration of $60 \mu \mathrm{g} / \mathrm{mL}$ of Emtricitabine, $90 \mu \mathrm{g} / \mathrm{mL}$ of Tenofovir Disoproxil Fumarate, $45 \mu \mathrm{g} / \mathrm{mL}$ of Cobicistat and 45 $\mu \mathrm{g} / \mathrm{mL}$ of Elvitegravir was injected six times into the UPLC system and the RSD \% for the assay of six replicate injections was calculated as mentioned in Table 7 and 8. Acceptance Criteria: The RSD \% for the assay of six sample injections should not be more than $2 \%$.

Table 7. Ruggedness data for Emtricitabine and Tenofovir Disoproxil Fumarate.

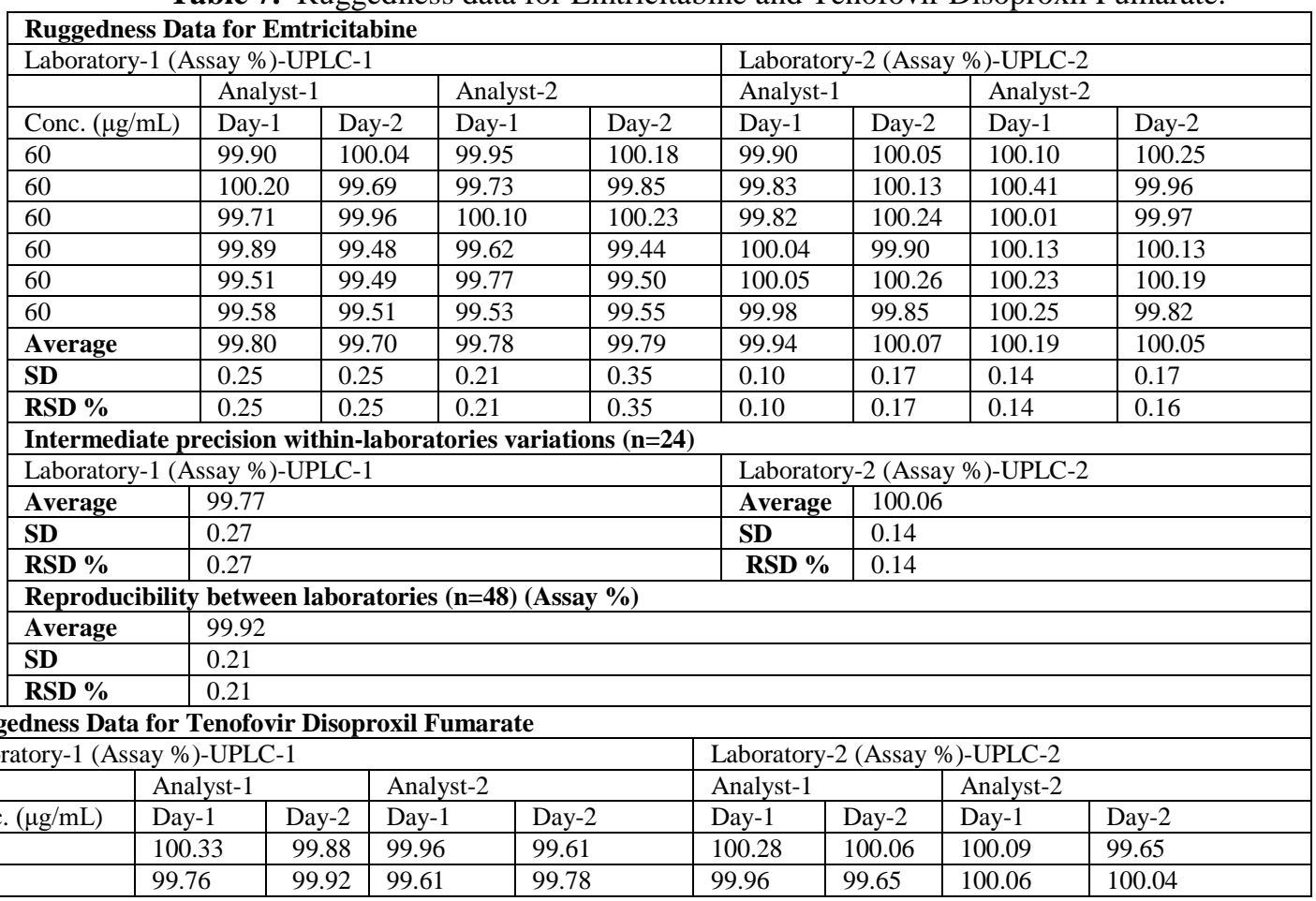


A novel validated RP-UPLC-DAD method for the simultaneous estimation of Emtricitabine, ..

\begin{tabular}{|c|c|c|c|c|c|c|c|c|}
\hline 90 & 99.78 & 99.70 & 99.94 & 99.80 & 99.98 & 99.29 & 100.05 & 99.72 \\
\hline 90 & 100.21 & 99.78 & 99.95 & 99.86 & 100.14 & 99.72 & 99.76 & 99.89 \\
\hline 90 & 99.16 & 99.99 & 99.69 & 99.92 & 100.06 & 99.37 & 100.05 & 100.14 \\
\hline 90 & 99.65 & 99.75 & 99.74 & 99.54 & 99.98 & 100.41 & 100.15 & 99.69 \\
\hline Average & 99.82 & 99.84 & 99.82 & 99.75 & 100.07 & 99.75 & 100.03 & 99.85 \\
\hline SD & 0.42 & 0.11 & 0.15 & 0.15 & 0.12 & 0.42 & 0.14 & 0.20 \\
\hline RSD \% & 0.42 & 0.11 & 0.15 & 0.15 & 0.12 & 0.42 & 0.14 & 0.20 \\
\hline \multicolumn{9}{|c|}{ Intermediate precision within-laboratories variations $(n=24)$} \\
\hline \multicolumn{5}{|c|}{ Laboratory-1 (Assay \%)-UPLC-1 } & \multicolumn{4}{|c|}{ Laboratory-2 (Assay \%)-UPLC-2 } \\
\hline Average & \multicolumn{4}{|c|}{99.81} & Average & \multicolumn{3}{|c|}{99.92} \\
\hline SD & \multicolumn{4}{|l|}{0.21} & SD & \multicolumn{3}{|l|}{0.22} \\
\hline RSD \% & \multicolumn{4}{|c|}{0.21} & RSD \% & \multicolumn{3}{|l|}{0.22} \\
\hline \multicolumn{9}{|c|}{ Reproducibility between laboratories $(n=48)($ Assay \%) } \\
\hline Average & \multicolumn{8}{|c|}{99.86} \\
\hline SD & \multicolumn{8}{|l|}{0.21} \\
\hline RSD \% & \multicolumn{8}{|l|}{0.21} \\
\hline
\end{tabular}

Table 8. Ruggedness data for Cobicistat and Elvitegravir.

\begin{tabular}{|c|c|c|c|c|c|c|c|c|}
\hline \multicolumn{9}{|c|}{ Ruggedness Data for Cobicistat } \\
\hline \multicolumn{5}{|c|}{ Laboratory-1 (Assay \%)-UPLC-1 } & \multicolumn{4}{|c|}{ Laboratory-2 (Assay \%)-UPLC-2 } \\
\hline \multirow{2}{*}{ Conc. $(\mu \mathrm{g} / \mathrm{mL})$} & \multicolumn{2}{|c|}{ Analyst-1 } & \multicolumn{2}{|c|}{ Analyst-2 } & \multicolumn{2}{|c|}{ Analyst-1 } & \multicolumn{2}{|c|}{ Analyst-2 } \\
\hline & \multicolumn{2}{|c|}{ Day-1 } & \multicolumn{2}{|c|}{ Day-1 } & \multicolumn{2}{|l|}{ Day-1 } & \multicolumn{2}{|c|}{ Day-1 } \\
\hline 45 & 99.43 & 99.82 & 99.88 & 100.18 & 100.23 & 100.06 & 100.14 & 99.86 \\
\hline 45 & 100.30 & 100.27 & 100.15 & 100.15 & 100.24 & 100.27 & 100.01 & 99.75 \\
\hline 45 & 99.89 & 100.07 & 99.96 & 99.54 & 100.12 & 99.54 & 100.06 & 100.04 \\
\hline 45 & 99.69 & 100.11 & 99.95 & 100.11 & 99.95 & 99.74 & 100.08 & 100.11 \\
\hline 45 & 99.27 & 100.07 & 100.24 & 99.75 & 99.86 & 100.07 & 99.43 & 99.89 \\
\hline 45 & 100.22 & 99.98 & 100.03 & 99.60 & 99.89 & 99.92 & 100.23 & 100.23 \\
\hline Average & 99.80 & 100.05 & 100.03 & 99.89 & 100.05 & 99.93 & 99.99 & 99.98 \\
\hline SD & 0.42 & 0.15 & 0.14 & 0.29 & 0.17 & 0.26 & 0.28 & 0.18 \\
\hline RSD \% & 0.42 & \begin{tabular}{l|l|} 
& 0.15 \\
\end{tabular} & \begin{tabular}{l|l} 
& 0.14 \\
\end{tabular} & 0.29 & 0.17 & 0.26 & 0.28 & 0.18 \\
\hline \multicolumn{9}{|c|}{ Intermediate precision within-laboratories variations $(\mathbf{n}=\mathbf{2 4})$} \\
\hline \multicolumn{5}{|c|}{ Laboratory-1 (Assay \%)-UPLC-1 } & \multicolumn{4}{|c|}{ Laboratory-2 (Assay \%)-UPLC-2 } \\
\hline \multicolumn{5}{|c|}{\begin{tabular}{|l|l|} 
Average & 99.94 \\
\end{tabular}} & Average & \multicolumn{3}{|c|}{99.99} \\
\hline SD & \multicolumn{4}{|l|}{\begin{tabular}{l|l} 
& 0.25 \\
\end{tabular}} & SD & \multicolumn{3}{|l|}{0.22} \\
\hline RSD \% & \multicolumn{4}{|l|}{0.25} & RSD \% & \multicolumn{3}{|l|}{0.22} \\
\hline \multicolumn{9}{|c|}{ Reproducibility between laboratories $(\mathrm{n}=48)($ Assay \%) } \\
\hline Average & \multicolumn{8}{|c|}{99.97} \\
\hline SD & 0.24 & & & & & & & \\
\hline RSD \% & 0.24 & & & & & & & \\
\hline Ruggedness D & ta for Elvi & avir & & & & & & \\
\hline Laboratory-1 ( & Assay \%)-Ur & & & & Laboratory & Assay \%)-U & & \\
\hline & Analyst-1 & & Analyst-2 & & Analyst-1 & & Analyst-2 & \\
\hline $\begin{array}{l}\text { Conc. } \\
(\mu \mathrm{g} / \mathrm{mL})\end{array}$ & Day-1 & Day-2 & Day-1 & Day-2 & Day-1 & Day-2 & Day-1 & Day-2 \\
\hline 45 & 99.55 & 99.76 & 99.75 & 99.82 & 99.81 & 99.95 & 99.26 & 99.86 \\
\hline 45 & 99.99 & 99.79 & 99.76 & 99.78 & 99.76 & 99.47 & 99.93 & 100.06 \\
\hline 45 & 100.08 & 100.01 & 100.12 & 100.01 & 100.05 & 99.84 & 100.04 & 100.04 \\
\hline 45 & 99.33 & 99.37 & 99.71 & 99.37 & 99.34 & 99.81 & 100.16 & 100.13 \\
\hline 45 & 100.82 & 99.57 & 99.68 & 99.57 & 99.75 & 100.02 & 100.02 & 100.32 \\
\hline 45 & 99.02 & 100.10 & 100.13 & 100.10 & 100.11 & 99.17 & 100.18 & 100.06 \\
\hline Average & 99.80 & 99.77 & 99.86 & 99.78 & 99.80 & 99.71 & 99.93 & 100.08 \\
\hline SD & 0.64 & 0.27 & 0.21 & 0.27 & 0.28 & 0.33 & 0.34 & 0.15 \\
\hline RSD \% & 0.64 & 0.27 & 0.21 & 0.27 & 0.28 & 0.33 & 0.34 & 0.15 \\
\hline Intermediate $\mathrm{p}$ & recision wi & -laboratorie & ariations (n & & & & & \\
\hline Laboratory-1 ( & Assay \%)-Ur & & & & Laboratory & Assay \%)-U & & \\
\hline Average & 99.80 & & & & Average & 99.88 & & \\
\hline SD & 0.35 & & & & SD & 0.27 & & \\
\hline RSD \% & 0.35 & & & & RSD \% & 0.27 & & \\
\hline Reproducibilit & y between l & ratories $(\mathbf{n}=4$ & (Assay \%) & & & & & \\
\hline Average & 99.84 & & & & & & & \\
\hline SD & 0.31 & & & & & & & \\
\hline RSD \% & 0.31 & & & & & & & \\
\hline
\end{tabular}

\subsubsection{Limit of Detection (LOD) and Limit of Quantification (LOQ)}

Limit of Detection (LOD) and Limit of Quantification (LOQ) were calculated as $3.3 \times \mathrm{SD} / \mathrm{S}$ and $10 \times \mathrm{SD} / \mathrm{S}$ respectively as per ICH guidelines, Where SD is the standard deviation of the response (Y-intercept) and $\mathrm{S}$ is the slope of the calibration curve. The LOD is the smallest concentration of the analyte that gives a measurable response (signal to noise ratio of 3). The LOD of Emtricitabine, Tenofovir Disoproxil Fumarate, 
A novel validated RP-UPLC-DAD method for the simultaneous estimation of Emtricitabine, ..

Cobicistat and Elvitegravir was calculated and shown in Table 9. The LOQ is the smallest concentration of the analyte which gives response that can be accurately quantified (signal to noise ratio of 10). The LOQ of Emtricitabine, Tenofovir Disoproxil Fumarate, Cobicistat and Elvitegravir was calculated and shown in Table 9.

Table 9. Summary of validation parameter for Emtricitabine, Tenofovir Disoproxil Fumarate, Cobicistat and Elvitegravir.

\begin{tabular}{|c|c|c|c|c|}
\hline \multirow[t]{2}{*}{ Parameters } & \multicolumn{4}{|l|}{ UPLC method } \\
\hline & \multicolumn{2}{|l|}{ Emtricitabine } & \multicolumn{2}{|c|}{ Tenofovir Disoproxil Fumarate } \\
\hline Linearity range $(\mu \mathrm{g} / \mathrm{mL})$ & \multicolumn{2}{|l|}{$20-100$} & \multicolumn{2}{|c|}{$30-150$} \\
\hline Slope & \multicolumn{2}{|l|}{11455} & \multicolumn{2}{|l|}{3093} \\
\hline Intercept & \multicolumn{2}{|l|}{9282} & \multicolumn{2}{|l|}{38.52} \\
\hline Correlation coefficient & \multicolumn{2}{|l|}{0.999} & \multicolumn{2}{|l|}{0.999} \\
\hline LOD $(\mu \mathrm{g} / \mathrm{mL})$ & \multicolumn{2}{|l|}{0.14} & \multicolumn{2}{|l|}{0.45} \\
\hline $\mathrm{LOQ}(\mu \mathrm{g} / \mathrm{mL})$ & \multicolumn{2}{|l|}{0.44} & \multicolumn{2}{|l|}{1.36} \\
\hline Method Precision (RSD \%, $\mathrm{n}=6$ ) & \multicolumn{2}{|l|}{0.18} & \multicolumn{2}{|l|}{0.64} \\
\hline System precision $(\mathrm{RSD} \%, \mathrm{n}=6)$ & \multicolumn{2}{|l|}{0.52} & \multicolumn{2}{|l|}{0.91} \\
\hline \multirow[b]{2}{*}{ Ruggedness (RSD \%, n=24) } & Lab-1 & Lab-2 & Lab-1 & Lab-2 \\
\hline & 0.27 & 0.14 & 0.21 & 0.22 \\
\hline Reproducibility (RSD \%, $\mathrm{n}=48$ ) & \multicolumn{2}{|l|}{0.21} & \multicolumn{2}{|l|}{0.21} \\
\hline Accuracy \% & \multicolumn{2}{|l|}{$99.55-99.96$} & \multicolumn{2}{|l|}{$100.04-100.07$} \\
\hline \multirow[t]{4}{*}{ Robustness (RSD \%, n=6) } & Less Flow rate & More Flow rate & Less Flow rate & More Flow rate \\
\hline & 0.21 & 0.16 & 0.55 & 0.23 \\
\hline & Less Organic phase & More Organic phase & Less Organic phase & More Organic phase \\
\hline & 0.02 & 0.09 & 0.07 & 0.11 \\
\hline \multirow[b]{2}{*}{ Parameters } & \multicolumn{4}{|l|}{ UPLC method } \\
\hline & \multicolumn{2}{|l|}{ Cobicistat } & Elvitegravir & \\
\hline Linearity range $(\mu \mathrm{g} / \mathrm{mL})$ & $15-75$ & & $15-75$ & \\
\hline Slope & 4020 & & 14719 & \\
\hline Intercept & 178.6 & & 3146 & \\
\hline Correlation coefficient & 0.999 & & 0.999 & \\
\hline $\mathrm{LOD}(\mu \mathrm{g} / \mathrm{mL})$ & 0.37 & & 0.25 & \\
\hline LOQ $(\mu \mathrm{g} / \mathrm{mL})$ & 1.12 & & 0.76 & \\
\hline Method Precision (RSD \%, $\mathrm{n}=6$ ) & 0.41 & & 0.79 & \\
\hline System precision $(\mathrm{RSD} \%, \mathrm{n}=6)$ & 0.85 & & 0.98 & \\
\hline & Lab-1 & Lab-2 & Lab-1 & Lab-2 \\
\hline Ruggedness (RSD \%, n=24) & 0.25 & 0.22 & 0.35 & 0.27 \\
\hline Reproducibility (RSD \%, n=48) & 0.24 & & 0.31 & \\
\hline Accuracy \% & $99.86-100.09$ & & $99.95-100.19$ & \\
\hline Robustness (RSD \%, n=6) & Less Flow rate & More Flow rate & Less Flow rate & More Flow rate \\
\hline & 0.83 & 0.34 & 0.84 & 0.79 \\
\hline & Less Organic phase & More Organic phase & Less Organic phase & More Organic phase \\
\hline & 0.08 & 0.34 & 0.03 & 0.23 \\
\hline
\end{tabular}

\subsubsection{Robustness}

As part of the Robustness, deliberate change in the flow rate and mobile phase proportion was made to evaluate the impact on the method. The results reveal that the method is robust. The results are summarized in Table 10 and 11.

Table 10. Summary of robustness (Change in flow rate) for Emtricitabine, Tenofovir Disoproxil Fumarate,

Cobicistat and Elvitegravir.

\begin{tabular}{|c|c|c|c|c|c|c|c|}
\hline \multirow[t]{2}{*}{ Drug } & \multirow{2}{*}{$\begin{array}{l}\text { Change in } \\
\text { Flow rate } \\
(\mathrm{mL} / \mathrm{min})\end{array}$} & \multirow{2}{*}{$\begin{array}{l}\text { Retention Time } \\
\text { (mins) }\end{array}$} & \multicolumn{5}{|c|}{ Change in flow Rate $(0.23 \mathrm{~mL} / \mathrm{min}$ to $0.27 \mathrm{~mL} / \mathrm{min})$} \\
\hline & & & $\begin{array}{l}\text { Average peak } \\
\text { area }(n=6)\end{array}$ & SD & RSD \% & $\begin{array}{l}\text { USP Plate } \\
\text { Count }\end{array}$ & Asymmetry \\
\hline \multirow[t]{3}{*}{ Emtricitabine } & 0.23 & 0.923 & 723555 & 1505.66 & 0.21 & 2077 & 1.36 \\
\hline & 0.25 & 0.904 & 698743 & 1932.22 & 0.28 & 2117 & 1.41 \\
\hline & 0.27 & 0.902 & 698270 & 1122.639 & 0.16 & 2584 & 1.39 \\
\hline \multirow{3}{*}{$\begin{array}{l}\text { Tenofovir } \\
\text { Disoproxil } \\
\text { Fumarate }\end{array}$} & 0.23 & 1.282 & 290212 & 1587.16 & 0.55 & 3239 & 1.4 \\
\hline & 0.25 & 1.240 & 284295 & 961.2957 & 0.34 & 3261 & 1.46 \\
\hline & 0.27 & 1.236 & 283224 & 638.9368 & 0.23 & 3220 & 1.45 \\
\hline \multirow[t]{3}{*}{ Cobicistat } & 0.23 & 2.806 & 188119 & 1568.46 & 0.83 & 7552 & 1.01 \\
\hline & 0.25 & 2.615 & 184005 & 1313.224 & 0.71 & 7064 & 1.02 \\
\hline & 0.27 & 2.602 & 183594 & 619.0691 & 0.34 & 7245 & 1.02 \\
\hline \multirow[t]{3}{*}{ Elvitegravir } & 0.23 & 4.141 & 688068 & 5760.38 & 0.84 & 9205 & 0.99 \\
\hline & 0.25 & 3.801 & 680457 & 2867.54 & 0.42 & 8757 & 0.98 \\
\hline & 0.27 & 3.786 & 680833 & 5347.351 & 0.79 & 8660 & 1.01 \\
\hline
\end{tabular}


A novel validated RP-UPLC-DAD method for the simultaneous estimation of Emtricitabine, ..

Table 11. Summary of robustness (Change in mobile phase) for Emtricitabine, Tenofovir Disoproxil Fumarate,

Cobicistat and Elvitegravir.

\begin{tabular}{|c|c|c|c|c|c|c|c|}
\hline \multirow[t]{2}{*}{ Drug } & \multirow[t]{2}{*}{$\begin{array}{l}\text { Change in Mobile } \\
\text { Phase }\end{array}$} & \multirow{2}{*}{$\begin{array}{l}\text { Retention } \\
\text { Time } \\
\text { (mins) }\end{array}$} & \multicolumn{5}{|c|}{$\begin{array}{l}\text { Change in mobile phase ( } 0.01 \mathrm{M} \text { Ammonium acetate buffer ( } \mathrm{pH} \text { adjusted to } \\
7.5 \text { with Ammonium hydroxide) and Acetonitrile) (50:50 v/v to } 40: 60 \mathrm{v} / \mathrm{v})\end{array}$} \\
\hline & & & $\begin{array}{l}\text { Average peak } \\
\text { area }(n=6)\end{array}$ & SD & RSD \% & $\begin{array}{l}\text { USP Plate } \\
\text { Count }\end{array}$ & Asymmetry \\
\hline \multirow[t]{3}{*}{ Emtricitabine } & $\begin{array}{l}10 \% \text { less Organic } \\
(50: 50 \mathrm{v} / \mathrm{v})\end{array}$ & 0.919 & 713300 & 169.9478 & 0.02 & 2458 & 1.34 \\
\hline & Actual $(45: 55 \mathrm{v} / \mathrm{v})$ & 0.904 & 698743 & 1932.22 & 0.28 & 2117 & 1.41 \\
\hline & $\begin{array}{l}10 \% \text { more Organic } \\
(40: 60 \mathrm{v} / \mathrm{v})\end{array}$ & 0.911 & 712761 & 628.535 & 0.09 & 2103 & 1.4 \\
\hline \multirow{3}{*}{$\begin{array}{l}\text { Tenofovir } \\
\text { Disoproxil } \\
\text { Fumarate }\end{array}$} & $\begin{array}{l}10 \% \text { less Organic } \\
(50: 50 \mathrm{v} / \mathrm{v})\end{array}$ & 1.321 & 285477 & 198.5115 & 0.07 & 3265 & 1.42 \\
\hline & Actual $(45: 55 \mathrm{v} / \mathrm{v})$ & 1.240 & 284295 & 961.2957 & 0.34 & 3261 & 1.46 \\
\hline & $\begin{array}{l}10 \% \text { more Organic } \\
(40: 60 \mathrm{v} / \mathrm{v})\end{array}$ & 1.224 & 287664 & 325.323 & 0.11 & 3159 & 1.44 \\
\hline \multirow[t]{3}{*}{ Cobicistat } & $\begin{array}{l}10 \% \text { less Organic } \\
(50: 50 \mathrm{v} / \mathrm{v})\end{array}$ & 3.204 & 188705 & 154.8974 & 0.08 & 7469 & 0.99 \\
\hline & Actual (45:55 v/v) & 2.615 & 184005 & 1313.224 & 0.71 & 7064 & 1.02 \\
\hline & $\begin{array}{l}10 \% \text { more Organic } \\
(40: 60 \mathrm{v} / \mathrm{v})\end{array}$ & 2.439 & 187682 & 643.8105 & 0.34 & 7078 & 1.05 \\
\hline \multirow[t]{3}{*}{ Elvitegravir } & $\begin{array}{l}10 \% \text { less Organic } \\
(50: 50 \mathrm{v} / \mathrm{v})\end{array}$ & 4.733 & 675634 & 212.3052 & 0.03 & 8827 & 0.97 \\
\hline & Actual $(45: 55 \mathrm{v} / \mathrm{v})$ & 3.801 & 680457 & 2867.54 & 0.42 & 8757 & 0.98 \\
\hline & $\begin{array}{l}10 \% \text { more Organic } \\
(40: 60 \mathrm{v} / \mathrm{v})\end{array}$ & 3.596 & 686369 & 1609.987 & 0.23 & 9034 & 1.01 \\
\hline
\end{tabular}

\subsubsection{Stability of solution}

The RSD \% of the assay of Emtricitabine, Tenofovir Disoproxil Fumarate, Cobicistat and Elvitegravir from the solution stability and mobile phase stability experiments was within $2 \%$. The results of the solution and mobile phase stability experiments confirm that the sample solutions and mobile phase used during the assays were stable upto 48 hours at room temperature was calculated and shown in Table 12.

Table 12. Summary of solution stability-effect of $\mathrm{P}^{\mathrm{H}}$ of mobile phase $(0.01 \mathrm{M}$ Ammonium acetate buffer and Acetonitrile (45:55, v/v) $\left(\mathrm{P}^{\mathrm{H}}\right.$ adjusted to 7.5 with Ammonium hydroxide) for Emtricitabine, Tenofovir Disoproxil Fumarate, Cobicistat and Elvitegravir for 48 hours at room temperature.

\begin{tabular}{|c|c|c|c|c|c|c|}
\hline & \multicolumn{6}{|c|}{ Solution stability for Emtricitabine } \\
\hline S.No. & $\begin{array}{l}\text { Concentration } \\
(\mu \mathrm{g} / \mathrm{mL})\end{array}$ & $\begin{array}{l}\text { Retention } \\
\text { time (min) }\end{array}$ & $\begin{array}{l}\text { Peak } \\
\text { Area }\end{array}$ & Assay \% & USP Plate Count & Asymmetry \\
\hline 1 & 60 & 0.922 & 713796 & 99.84 & 2113 & 1.41 \\
\hline 2 & 60 & 0.927 & 715905 & 100.14 & 2108 & 1.4 \\
\hline 3 & 60 & 0.919 & 712443 & 99.65 & 2117 & 1.39 \\
\hline 4 & 60 & 0.918 & 713735 & 99.84 & 2114 & 1.41 \\
\hline 5 & 60 & 0.920 & 711003 & 99.45 & 2116 & 1.4 \\
\hline 6 & 60 & 0.921 & 711485 & 99.52 & 2114 & 1.41 \\
\hline \multicolumn{2}{|l|}{ Average } & 0.921 & 713061.2 & 99.74 & 2114 & 1.403333 \\
\hline \multicolumn{2}{|l|}{ SD } & 0.003189 & 1799.105 & 0.2517 & 3.141125 & 0.008165 \\
\hline \multicolumn{2}{|c|}{ RSD \% } & 0.35 & 0.25 & 0.25 & 0.15 & 0.58 \\
\hline \multicolumn{7}{|c|}{ Solution stability for Tenofovir Disoproxil Fumarate } \\
\hline S.No. & \begin{tabular}{|l|l} 
& $\begin{array}{l}\text { Concentration } \\
(\mu \mathrm{g} / \mathrm{mL})\end{array}$
\end{tabular} & $\begin{array}{l}\text { Retention } \\
\text { time }(\min )\end{array}$ & $\begin{array}{l}\text { Peak } \\
\text { Area }\end{array}$ & Assay \% & USP Plate Count & Asymmetry \\
\hline 1 & 90 & 1.284 & 289957 & 100.29 & 3261 & 1.41 \\
\hline 2 & 90 & 1.291 & 288321 & 99.73 & 3278 & 1.41 \\
\hline 3 & 90 & 1.282 & 288393 & 99.75 & 3234 & 1.4 \\
\hline 4 & 90 & 1.279 & 289629 & 100.18 & 3283 & 1.42 \\
\hline 5 & 90 & 1.283 & 286603 & 99.13 & 3265 & 1.43 \\
\hline 6 & 90 & 1.284 & 287797 & 99.54 & 3269 & 1.41 \\
\hline \multicolumn{2}{|l|}{ Average } & 1.284 & 288450 & 99.77 & 3265 & 1.413333 \\
\hline \multicolumn{2}{|l|}{ SD } & 0.003971 & 1226.279 & 0.4241 & 17.23949 & 0.010328 \\
\hline \multicolumn{2}{|c|}{ RSD \% } & 0.31 & 0.43 & 0.43 & 0.53 & 0.73 \\
\hline \multicolumn{7}{|c|}{ Solution stability for Cobicistat } \\
\hline S.No. & \begin{tabular}{|l|l} 
& $\begin{array}{l}\text { Concentration } \\
(\mu \mathrm{g} / \mathrm{mL})\end{array}$ \\
\end{tabular} & $\begin{array}{l}\text { Retention } \\
\text { time (min) }\end{array}$ & $\begin{array}{l}\text { Peak } \\
\text { Area }\end{array}$ & Assay \% & USP Plate Count & Asymmetry \\
\hline 1 & 45 & 2.835 & 186307 & 99.43 & 7064 & 1.02 \\
\hline 2 & 45 & 2.839 & 187952 & 100.30 & 7218 & 1.03 \\
\hline 3 & 45 & 2.823 & 187181 & 99.89 & 7223 & 1.02 \\
\hline 4 & 45 & 2.822 & 186797 & 99.69 & 7115 & 1.02 \\
\hline 5 & 45 & 2.831 & 186013 & 99.27 & 7110 & 1.01 \\
\hline 6 & 45 & 2.834 & 187804 & 100.22 & 7213 & 1.03 \\
\hline
\end{tabular}


A novel validated RP-UPLC-DAD method for the simultaneous estimation of Emtricitabine, ..

\begin{tabular}{|c|c|c|c|c|c|c|}
\hline \multicolumn{2}{|l|}{ Average } & 2.831 & 187009 & 99.80 & 7157.167 & 1.021667 \\
\hline \multicolumn{2}{|l|}{ SD } & 0.006831 & 784.9359 & 0.4189 & 69.04322 & 0.007528 \\
\hline \multicolumn{2}{|c|}{ RSD \% } & 0.24 & 0.42 & 0.42 & 0.96 & 0.74 \\
\hline \multicolumn{7}{|c|}{ Solution stability for Elvitegravir } \\
\hline S.No. & $\begin{array}{l}\text { Concentration } \\
(\mu \mathrm{g} / \mathrm{mL})\end{array}$ & $\begin{array}{l}\text { Retention } \\
\text { time (min) }\end{array}$ & $\begin{array}{l}\text { Peak } \\
\text { Area }\end{array}$ & Assay \% & USP Plate Count & Asymmetry \\
\hline 1 & 45 & 4.166 & 677081 & 99.70 & 8757 & 0.98 \\
\hline 2 & 45 & 4.175 & 679055 & 99.99 & 8528 & 0.99 \\
\hline 3 & 45 & 4.150 & 679669 & 100.08 & 8738 & 0.99 \\
\hline 4 & 45 & 4.150 & 674577 & 99.33 & 8629 & 0.99 \\
\hline 5 & 45 & 4.166 & 684694 & 100.82 & 8739 & 0.99 \\
\hline 6 & 45 & 4.168 & 672451 & 99.02 & 8751 & 0.98 \\
\hline \multicolumn{2}{|l|}{ Average } & 4.163 & 677921.2 & 99.82 & 8690.333 & 0.986667 \\
\hline \multicolumn{2}{|l|}{ SD } & 0.010232 & 4290.078 & 0.6317 & 92.60598 & 0.005164 \\
\hline \multicolumn{2}{|l|}{ RSD \% } & 0.25 & 0.63 & 0.63 & 1.06 & 0.52 \\
\hline
\end{tabular}

\subsubsection{Forced degradation studies}

\subsubsection{Acid Degradation Studies}

To $1 \mathrm{~mL}$ of stock solution of Emtricitabine, Tenofovir Disoproxil Fumarate, Cobicistat and Elvitegravir, $1 \mathrm{~mL}$ of $2 \mathrm{~N}$ Hydrochloric acid was added and refluxed for $30 \mathrm{mins}$ at $60^{\circ} \mathrm{C}$. The resultant solution was diluted to obtain $60 \mu \mathrm{g} / \mathrm{mL}$ of Emtricitabine, $90 \mu \mathrm{g} / \mathrm{mL}$ of Tenofovir Disoproxil Fumarate, 45 $\mu \mathrm{g} / \mathrm{mL}$ of Cobicistat and $45 \mu \mathrm{g} / \mathrm{mL}$ of Elvitegravir solution and $20 \mu \mathrm{L}$ solutions were injected into the UPLC system and the chromatogram were recorded to assess the stability of sample was shown in figure 8 and purity plot of acid degradation for Emtricitabine, Tenofovir Disoproxil Fumarate, Cobicistat and Elvitegravir was shown in figure 9 .

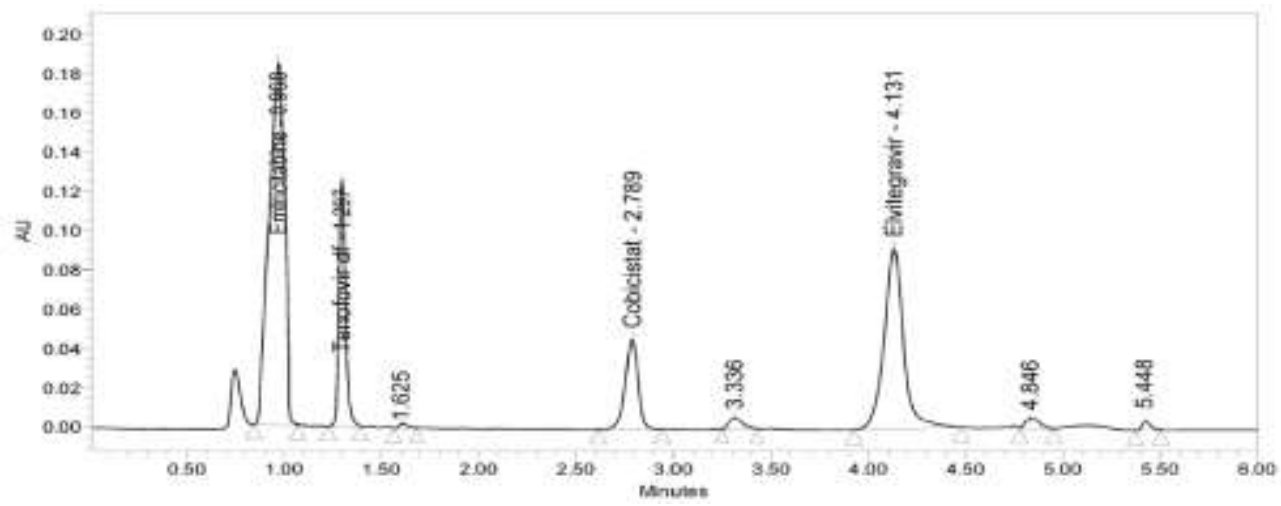

Figure 8: Chromatogram of acid hydrolysis for Emtricitabine, Tenofovir Disoproxil Fumarate, Cobicistat and Elvitegravir.

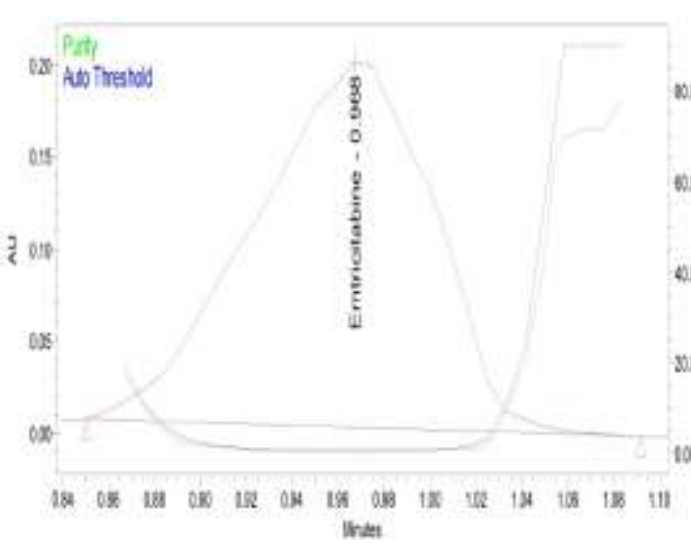

(A)

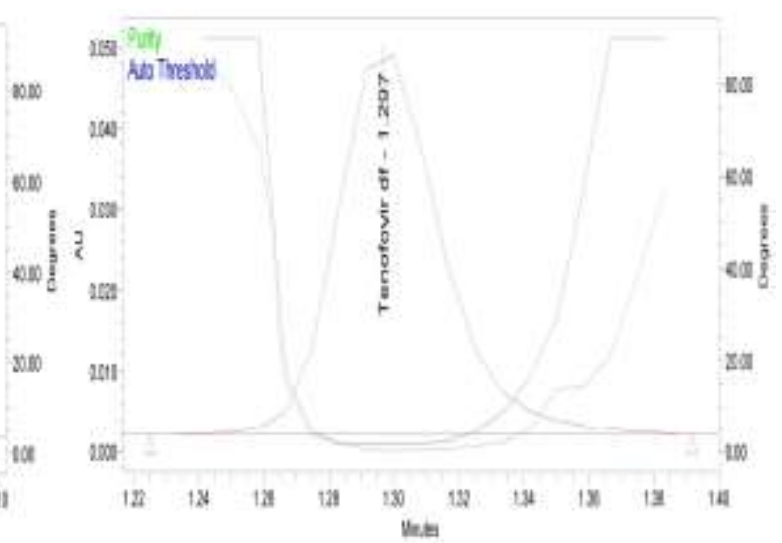

(B) 


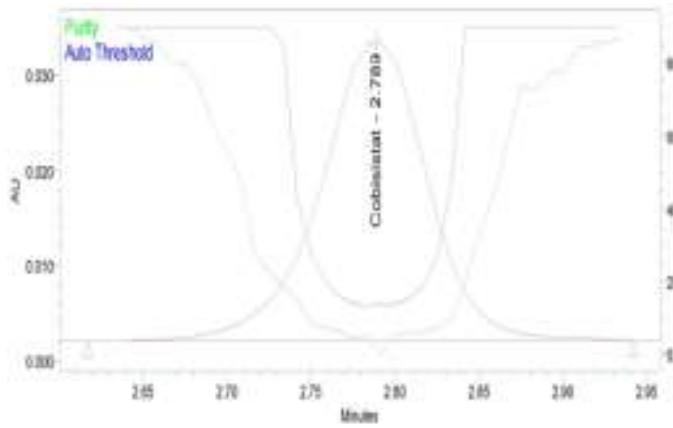

(C)

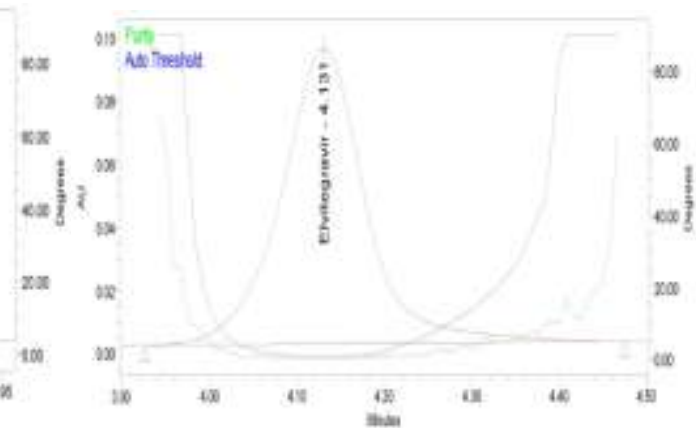

(D)

Figure 9: Purity plot of acid hydrolysis for (A) Emtricitabine (B) Tenofovir Disoproxil Fumarate (C) Cobicistat (D) Elvitegravir.

\subsubsection{Alkali Degradation Studies}

To $1 \mathrm{~mL}$ of stock solution of Emtricitabine, Tenofovir Disoproxil Fumarate, Cobicistat and Elvitegravir, $1 \mathrm{~mL}$ of $2 \mathrm{~N}$ sodium hydroxide was added and refluxed for 30 mins at $60^{\circ} \mathrm{C}$. The resultant solution was diluted to obtain $60 \mu \mathrm{g} / \mathrm{mL}$ of Emtricitabine, $90 \mu \mathrm{g} / \mathrm{mL}$ of Tenofovir Disoproxil Fumarate, 45 $\mu \mathrm{g} / \mathrm{mL}$ of Cobicistat and $45 \mu \mathrm{g} / \mathrm{mL}$ of Elvitegravir solution and $20 \mu \mathrm{L}$ solutions were injected into the UPLC system and the chromatogram were recorded to assess the stability of sample was shown in figure 10 and purity plot of alkali degradation for Emtricitabine, Tenofovir Disoproxil Fumarate, Cobicistat and Elvitegravir was shown in figure 11.

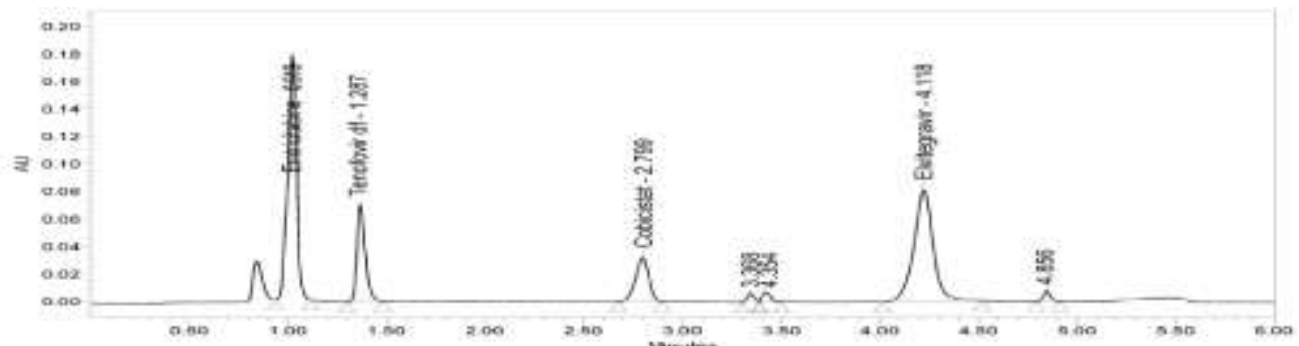

Figure 10: Chromatogram of alkali hydrolysis for Emtricitabine, Tenofovir Disoproxil Fumarate, Cobicistat and Elvitegravir.

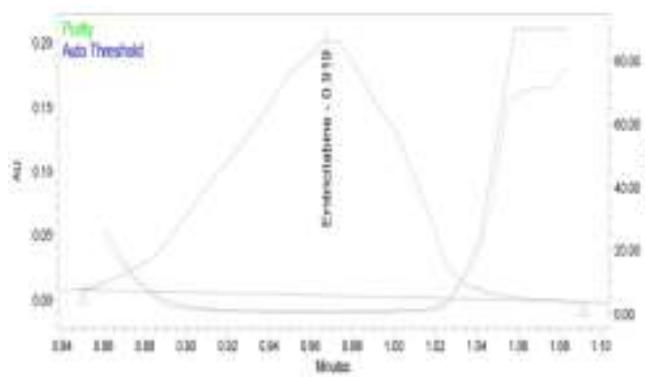

(A)

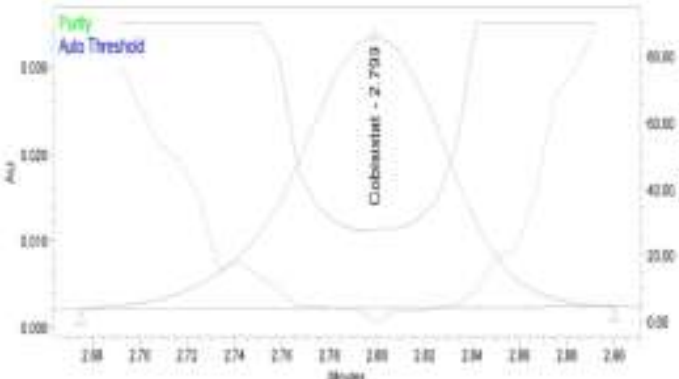

(C)

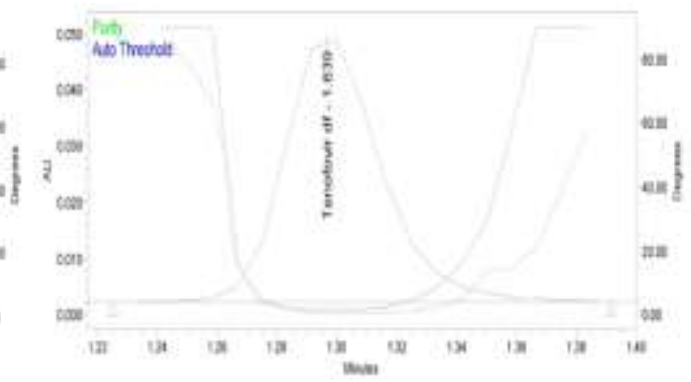

(B)

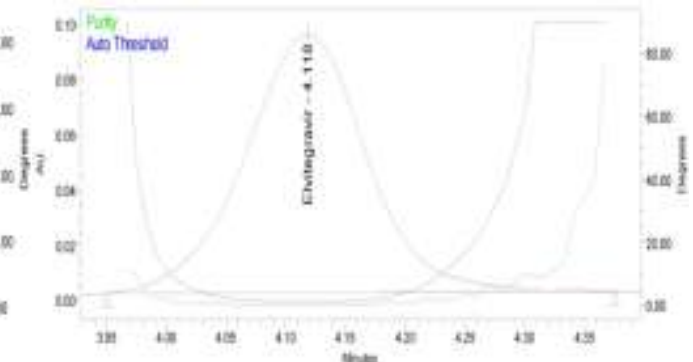

(D)

Figure 11: Purity plot of alkali degradation for (A) Emtricitabine (B) Tenofovir Disoproxil Fumarate (C)

Cobicistat (D) Elvitegravir. 


\subsubsection{Oxidative degradation Studies}

To $1 \mathrm{~mL}$ of stock solution of Emtricitabine, Tenofovir Disoproxil Fumarate, Cobicistat and Elvitegravir, $1 \mathrm{~mL}$ of $3 \%$ Hydrogen peroxide $\left(\mathrm{H}_{2} \mathrm{O}_{2}\right)$ was added and the solution was kept for 30 mins at $60^{\circ} \mathrm{C}$. For UPLC study, the resultant solution was diluted to obtain $60 \mu \mathrm{g} / \mathrm{mL}$ of Emtricitabine, 90 $\mu \mathrm{g} / \mathrm{mL}$ of Tenofovir Disoproxil Fumarate, $45 \mu \mathrm{g} / \mathrm{mL}$ of Cobicistat and $45 \mu \mathrm{g} / \mathrm{mL}$ of Elvitegravir solution and $20 \mu \mathrm{L}$ solutions were injected into the UPLC system and the chromatogram were recorded to assess the stability of sample was shown in figure 12 and purity plot of oxidative degradation for Emtricitabine, Tenofovir Disoproxil Fumarate, Cobicistat and Elvitegravir was shown in figure 13.

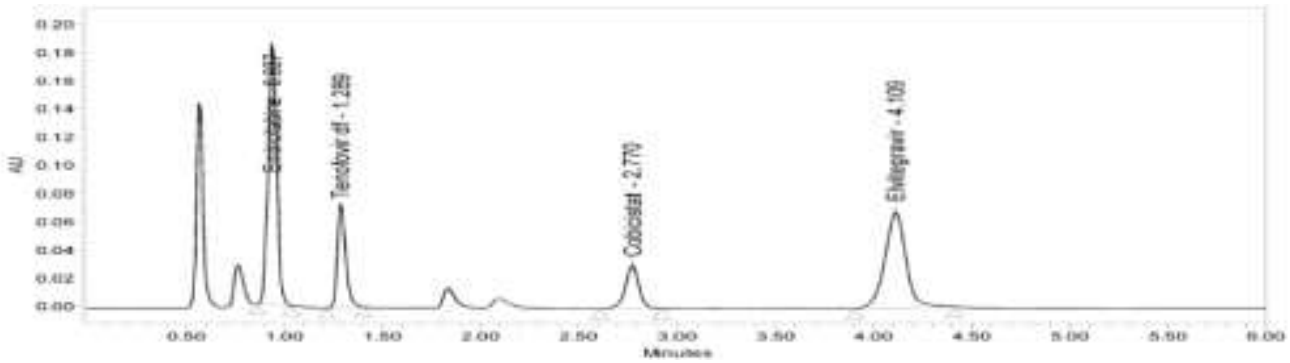

Figure 12: Chromatogram of oxidative degradation for Emtricitabine, Tenofovir Disoproxil Fumarate, Cobicistat and Elvitegravir.

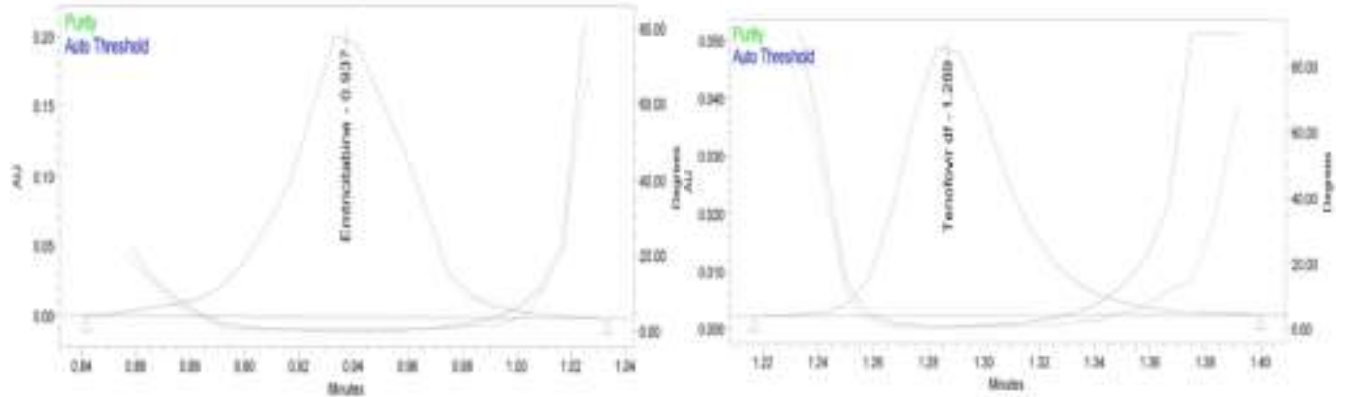

(A)

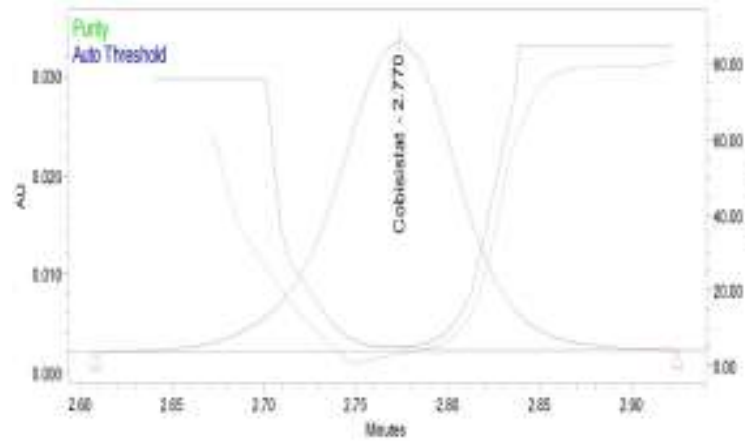

(C)
(B)

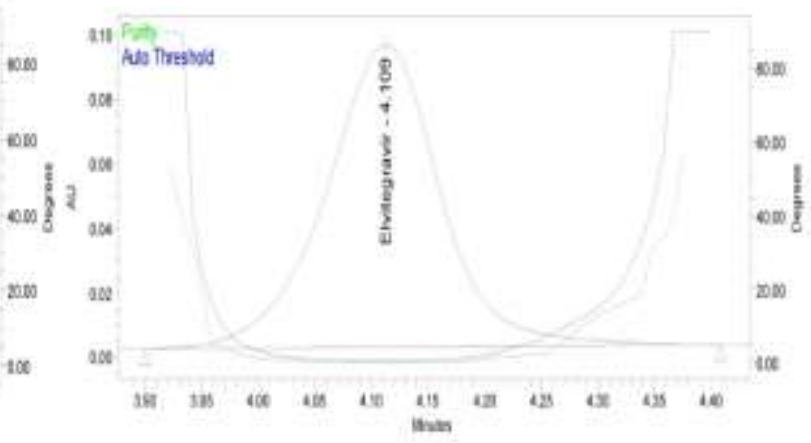

(D)

Figure 13: Purity plot of oxidative degradation for (A) Emtricitabine (B) Tenofovir Disoproxil Fumarate (C) Cobicistat (D) Elvitegravir.

\subsubsection{Photolytic degradation studies}

The photochemical stability of the drug was also studied by exposing the drug solution to UV light by keeping the beaker in UV Chamber for 7 days or 200 Watt hours $/ \mathrm{m}^{2}$ in photo stability chamber. For UPLC study, the resultant solution was diluted to obtain $60 \mu \mathrm{g} / \mathrm{mL}$ of Emtricitabine, $90 \mu \mathrm{g} / \mathrm{mL}$ of Tenofovir Disoproxil Fumarate, $45 \mu \mathrm{g} / \mathrm{mL}$ of Cobicistat and $45 \mu \mathrm{g} / \mathrm{mL}$ of Elvitegravir solution and $20 \mu \mathrm{L}$ solutions were injected into the UPLC system and the chromatogram were recorded to assess the stability of sample was shown in figure 14 and purity plot of photolytic degradation for Emtricitabine, Tenofovir Disoproxil Fumarate, Cobicistat and Elvitegravir was shown in figure 15. 


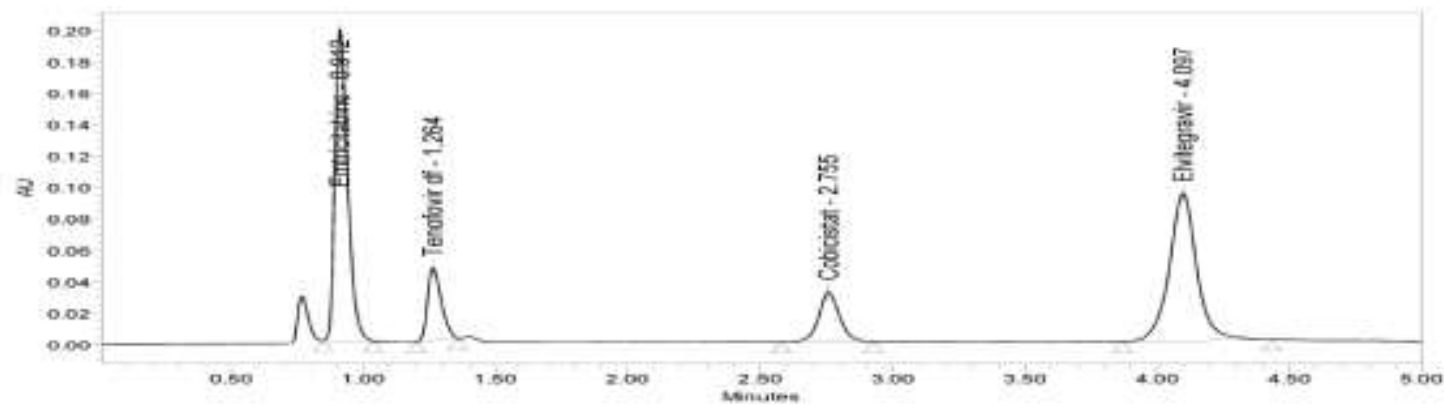

Figure 14: Chromatogram of photolytic degradation for Emtricitabine, Tenofovir Disoproxil Fumarate, Cobicistat and Elvitegravir.

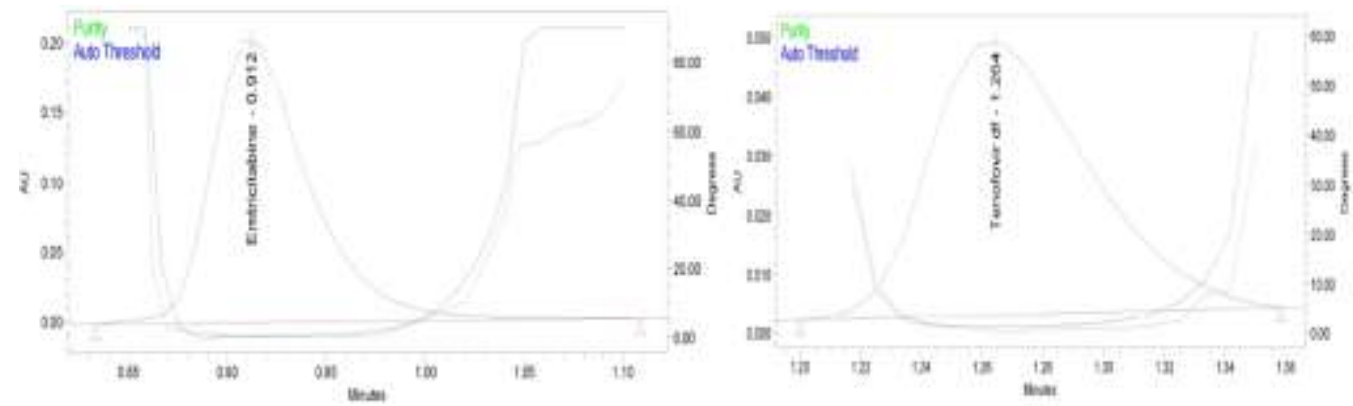

(A)

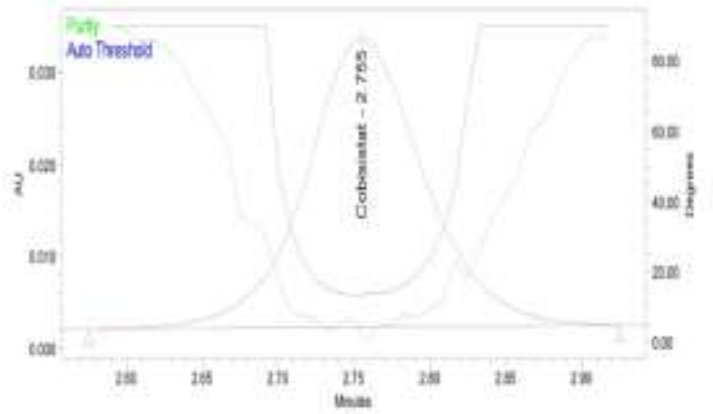

(C)
(B)

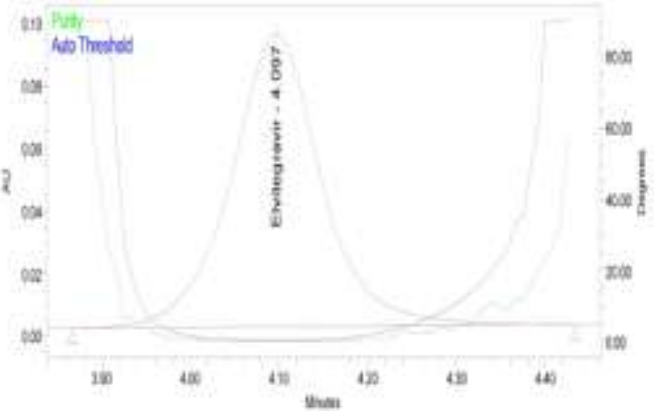

(D)

Figure 15: Purity plot of photolytic degradation for (A) Emtricitabine (B) Tenofovir Disoproxil Fumarate (C) Cobicistat (D) Elvitegravir.

\subsubsection{Thermal Degradation Studies}

The standard drug solution was placed in an oven at $105^{\circ} \mathrm{C}$ for 6 hrs to study dry heat degradation. For UPLC study, the resultant solution was diluted to $60 \mu \mathrm{g} / \mathrm{mL}$ of Emtricitabine, $90 \mu \mathrm{g} / \mathrm{mL}$ of Tenofovir Disoproxil Fumarate, $45 \mu \mathrm{g} / \mathrm{mL}$ of Cobicistat and $45 \mu \mathrm{g} / \mathrm{mL}$ of Elvitegravir solution and $20 \mu \mathrm{L}$ solutions were injected into the UPLC system and the chromatogram were recorded to assess the stability of sample was shown in figure 16 and purity plot of thermal degradation for Emtricitabine, Tenofovir Disoproxil Fumarate, Cobicistat and Elvitegravir was shown in figure 17.

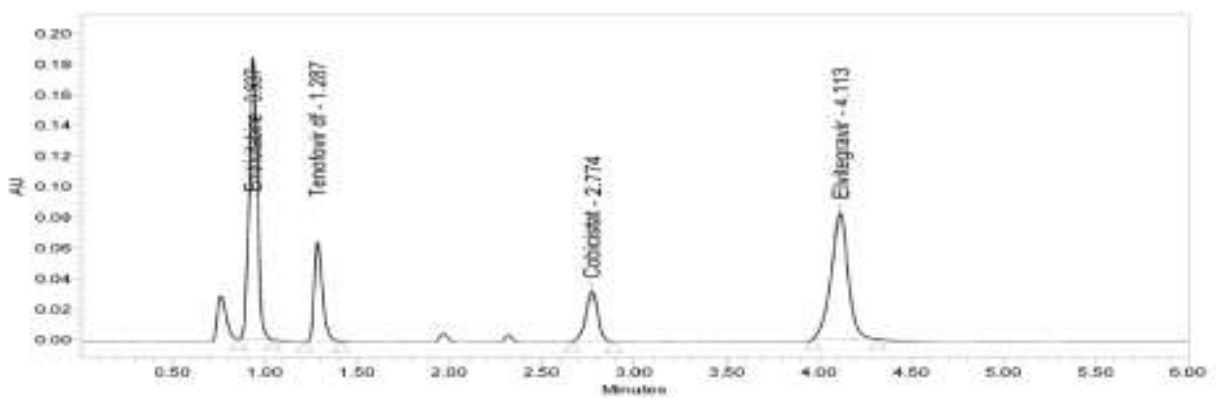

Figure 16: Chromatogram of thermal degradation for Emtricitabine, Tenofovir Disoproxil Fumarate, Cobicistat and Elvitegravir. 


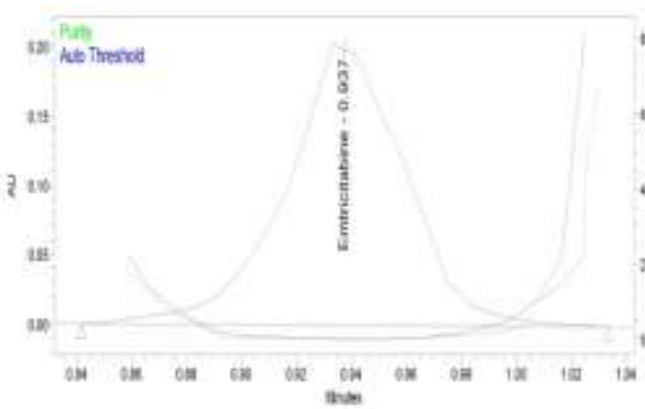

(A)

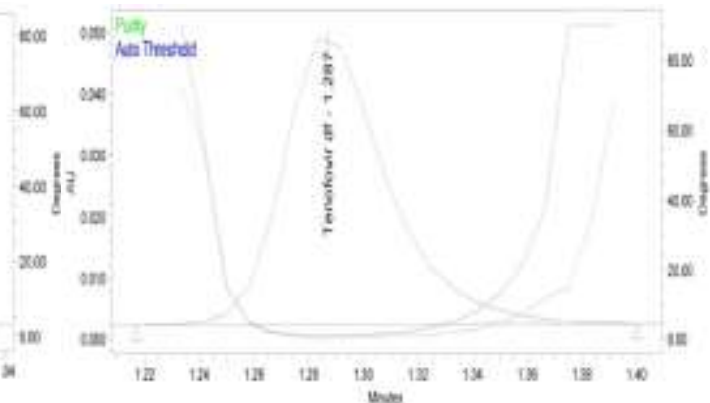

(B)

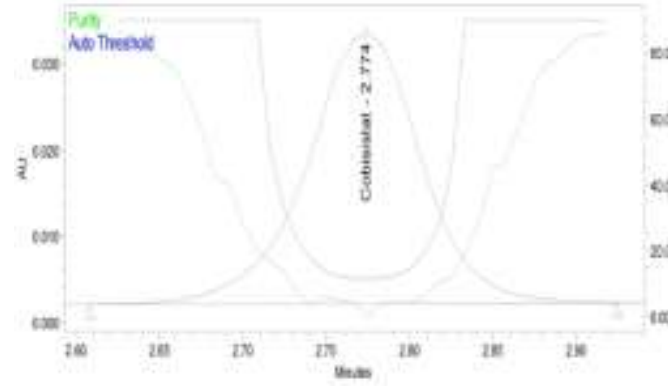

(C)

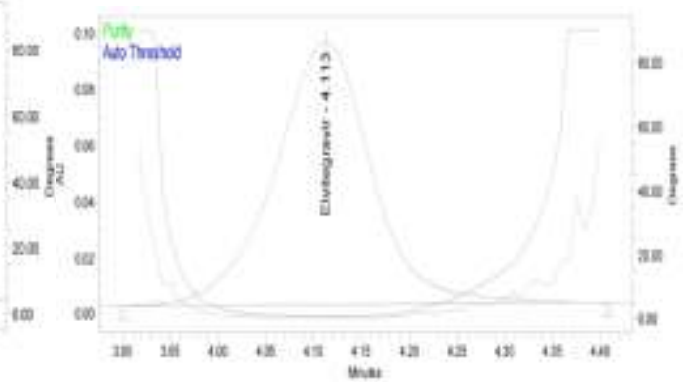

(D)

Figure 17: Purity plot of thermal degradation for (A) Emtricitabine (B) Tenofovir Disoproxil Fumarate (C) Cobicistat (D) Elvitegravir.

\section{Discussion}

This method was intended for rapid estimation of Emtricitabine, Tenofovir Disoproxil Fumarate, Cobicistat and Elvitegravir in bulk and pharmaceutical dosage form. Good separation of the chromatographic peaks was observed and no interfering peaks are found. A number of commercially available UPLC columns and various mobile phases were evaluated for its chromatographic behavior of Emtricitabine, Tenofovir Disoproxil Fumarate, Cobicistat and Elvitegravir. The best response were obtained with ACQUITY UPLC BEH $\mathrm{C}_{18}(100 \mathrm{~mm} \times 2.1 \mathrm{~mm}, 1.7 \mu \mathrm{m}$ particle size $)$ column, Waters ACQUITY UPLC system with PDA detector and mobile phase contained a mixture of $0.01 \mathrm{M}$ Ammonium acetate buffer (pH adjusted to 7.5 with ammonium hydroxide) and Acetonitrile $(45: 55, \mathrm{v} / \mathrm{v})$ was delivered at a flow rate of $0.25 \mathrm{~mL} / \mathrm{min}$. Quantification was achieved with PDA detection at $268 \mathrm{~nm}$ based on peak area. The retention time of Emtricitabine, Tenofovir Disoproxil Fumarate, Cobicistat and Elvitegravir was $0.904 \mathrm{~min}, 1.240 \mathrm{~min}, 2.615 \mathrm{~min}$ and 3.801 min with resolution of 4.05, 13.02 and 8.27 respectively. Linearity was established for Emtricitabine, Tenofovir Disoproxil Fumarate, Cobicistat and Elvitegravir in the range of $20-100 \mu \mathrm{g} / \mathrm{mL}$ for Emtricitabine, 30-150 $\mu \mathrm{g} / \mathrm{mL}$ for Tenofovir Disoproxil Fumarate, $15-75 \mu \mathrm{g} / \mathrm{mL}$ for Cobicistat and $15-75 \mu \mathrm{g} / \mathrm{mL}$ for Elvitegravir with correlation coefficients $\left(\mathrm{r}^{2}=0.999\right)$ and the percentage recoveries were between 99.55-99.96\%, 100.04-100.07 $\%, 99.86-100.09 \%$, and 99.95-100.19 \% for Emtricitabine, Tenofovir Disoproxil Fumarate, Cobicistat and Elvitegravir respectively, which indicate accuracy of the proposed method. The RSD \% values of accuracy for Emtricitabine, Tenofovir Disoproxil Fumarate, Cobicistat and Elvitegravir were found to be < $2 \%$. The RSD \% values of method precision are $0.18 \%, 0.64 \%, 0.41 \%$ and $0.79 \%$ for Emtricitabine, Tenofovir Disoproxil Fumarate, Cobicistat and Elvitegravir respectively and RSD \% values of system precision are $0.52 \%, 0.91 \%$, $0.85 \%$ and $0.98 \%$ for Emtricitabine, Tenofovir Disoproxil Fumarate, Cobicistat and Elvitegravir. The RSD \% values of reproducibility are $0.21 \%, 0.21 \%, 0.24 \%$ and $0.31 \%$ for Emtricitabine, Tenofovir Disoproxil Fumarate, Cobicistat and Elvitegravir respectively, reveal that the proposed method is precise. LOD values for Emtricitabine, Tenofovir Disoproxil Fumarate, Cobicistat and Elvitegravir were found to be $0.14 \mu \mathrm{g} / \mathrm{mL}, 0.45$ $\mu \mathrm{g} / \mathrm{mL}, 0.37 \mu \mathrm{g} / \mathrm{mL}$ and $0.25 \mu \mathrm{g} / \mathrm{mL}$ respectively and LOQ values for Emtricitabine, Tenofovir Disoproxil Fumarate, Cobicistat and Elvitegravir were found to be $0.44 \mu \mathrm{g} / \mathrm{mL}, 1.36 \mu \mathrm{g} / \mathrm{mL}, 1.12 \mu \mathrm{g} / \mathrm{mL}$ and $0.76 \mu \mathrm{g} / \mathrm{mL}$ respectively. The RSD \% values of robustness studies were found to be $<2 \%$ reveal that the method is robust enough. These data show that the proposed method is accurate and precise for the determination of Emtricitabine, Tenofovir Disoproxil Fumarate, Cobicistat and Elvitegravir in its bulk and pharmaceutical dosage form.

\section{Conclusion}

The present RP-UPLC-DAD method for simultaneous estimation of Emtricitabine, Tenofovir Disoproxil Fumarate, Cobicistat and Elvitegravir in their combine dosage form was established and validated as 
A novel validated RP-UPLC-DAD method for the simultaneous estimation of Emtricitabine, ..

per the ICH guidelines. Linearity was achieved for Emtricitabine, Tenofovir Disoproxil Fumarate, Cobicistat and Elvitegravir in the range of $20-100 \mu \mathrm{g} / \mathrm{mL}$ for Emtricitabine, $30-150 \mu \mathrm{g} / \mathrm{mL}$ for Tenofovir Disoproxil Fumarate, $15-75 \mu \mathrm{g} / \mathrm{mL}$ for Cobicistat and $15-75 \mu \mathrm{g} / \mathrm{mL}$ for Elvitegravir with correlation coefficients $\left(\mathrm{r}^{2}=0.999\right)$. The percentage recoveries of Emtricitabine, Tenofovir Disoproxil Fumarate, Cobicistat and Elvitegravir were achieved in the range of $98-102 \%$ which was within the acceptance criteria. The percentage RSD was NMT $2 \%$ which proved the precision of the developed method. The developed method is simple, sensitive, rapid, linear, precise, rugged, accurate, specific, and robust. The forced degradation studies were performed by using $\mathrm{HCl}, \mathrm{NaOH}, \mathrm{H}_{2} \mathrm{O}_{2}$, thermal, $\mathrm{UV}$ radiation. Emtricitabine are more sensitive towards alkaline hydrolysis degradation condition, Tenofovir Disoproxil Fumarate is more sensitive towards oxidative degradation condition, Cobicistat are more sensitive towards alkaline hydrolysis degradation condition and Elvitegravir are more sensitive towards acidic hydrolysis degradation condition which was shown in Table 13 and 14. No interference from any components of pharmaceutical dosage form or degradation products was observed and the method has been successfully used to perform long term and accelerated stability studies of Emtricitabine, Tenofovir Disoproxil Fumarate, Cobicistat and Elvitegravir formulations. Hence it can be used for the hyphenated instrumental analysis of Emtricitabine, Tenofovir Disoproxil Fumarate, Cobicistat and Elvitegravir in their bulk and combine dosage form.

Table 13. Forced degradation data of Emtricitabine and Tenofovir Disoproxil Fumarate in different degradation conditions.

\begin{tabular}{|c|c|c|c|c|c|c|}
\hline \multicolumn{7}{|c|}{ Forced degradation data of Emtricitabine } \\
\hline \begin{tabular}{l|l}
$\begin{array}{l}\text { Degradation } \\
\text { condition }\end{array}$ & \\
\end{tabular} & $\begin{array}{l}\text { Retention time } \\
\text { (mins) }\end{array}$ & Area & $\begin{array}{l}\text { Purity } \\
\text { Angle }\end{array}$ & Purity Threshold & USP Plate Count & Asymmetry \\
\hline Acid hydrolysis & 0.968 & 648514 & 0.682 & 0.878 & 2502 & 0.86 \\
\hline $\begin{array}{l}\text { Alkaline } \\
\text { hydrolysis }\end{array}$ & 0.919 & 641573 & 0.526 & 0.869 & 2802 & 1.75 \\
\hline $\begin{array}{l}\text { Oxidative } \\
\text { degradation }\end{array}$ & 0.937 & 652632 & 0.325 & 0.627 & 2425 & 0.92 \\
\hline $\begin{array}{l}\text { Photolytic } \\
\text { degradation }\end{array}$ & 0.912 & 693862 & 0.452 & 0.581 & 2693 & 1.41 \\
\hline \begin{tabular}{|l|l} 
Thermal \\
degradation
\end{tabular} & 0.937 & 662559 & 0.384 & 0.531 & 2035 & 0.95 \\
\hline \multicolumn{7}{|c|}{ Forced degradation data of Tenofovir Disoproxil Fumarate } \\
\hline $\begin{array}{l}\text { Degradation } \\
\text { condition }\end{array}$ & \begin{tabular}{l|l}
$\begin{array}{l}\text { Retention } \\
\text { time(mins) }\end{array}$
\end{tabular} & Area & \begin{tabular}{l|l} 
Purity \\
Angle
\end{tabular} & Purity Threshold & USP Plate Count & Asymmetry \\
\hline Acid hydrolysis & 1.297 & 160580 & 2.162 & 2.335 & 7015 & 1.25 \\
\hline Alkaline hydrolysis & 1.639 & 155941 & 2.023 & 2.289 & 9381 & 1.11 \\
\hline $\begin{array}{l}\begin{array}{l}\text { Oxidative } \\
\text { degradation }\end{array} \\
\end{array}$ & 1.289 & 150625 & 0.869 & 1.436 & 8052 & 1.31 \\
\hline $\begin{array}{l}\text { Photolytic } \\
\text { degradation }\end{array}$ & 1.264 & 168874 & 1.599 & 1.807 & 2594 & 1.31 \\
\hline Thermal degradation & 1.287 & 152634 & 1.121 & 1.509 & 5068 & 1.35 \\
\hline \multirow{2}{*}{$\begin{array}{l}\text { Degradation } \\
\text { condition }\end{array}$} & \multicolumn{3}{|c|}{ Drug Recovered (\%) } & \multicolumn{3}{|c|}{ Drug Decomposed (\%) } \\
\hline & Emtricitabine & \multicolumn{2}{|c|}{$\begin{array}{l}\text { Tenofovir Disoproxil } \\
\text { Fumarate }\end{array}$} & Emtricitabine & \multicolumn{2}{|c|}{ Tenofovir Disoproxil Fumarate } \\
\hline Standard & 100 & \multicolumn{2}{|c|}{100} & 100 & \multicolumn{2}{|l|}{100} \\
\hline Acid hydrolysis & 93.32 & \multicolumn{2}{|l|}{94.94} & 6.68 & \multicolumn{2}{|l|}{5.06} \\
\hline Alkaline hydrolysis & 92.32 & \multicolumn{2}{|l|}{92.20} & 7.68 & \multicolumn{2}{|l|}{7.80} \\
\hline $\begin{array}{l}\text { Oxidative } \\
\text { degradation }\end{array}$ & 93.91 & \multicolumn{2}{|l|}{89.06} & 6.09 & \multicolumn{2}{|l|}{10.94} \\
\hline $\begin{array}{l}\text { Photolytic } \\
\text { degradation }\end{array}$ & 99.84 & \multicolumn{2}{|l|}{99.85} & 0.16 & \multicolumn{2}{|l|}{0.15} \\
\hline Thermal degradation & 95.34 & \multicolumn{2}{|l|}{90.25} & 4.66 & \multicolumn{2}{|l|}{9.75} \\
\hline
\end{tabular}

Table 14. Forced degradation data of Cobicistat and Elvitegravir in different degradation conditions. Forced degradation data of Cobicistat

\begin{tabular}{|c|c|c|c|c|c|c|}
\hline $\begin{array}{l}\text { Degradation } \\
\text { condition }\end{array}$ & $\begin{array}{l}\text { Retention } \\
\text { time (mins) }\end{array}$ & Area & Purity Angle & Purity Threshold & USP Plate Count & Asymmetry \\
\hline Acid hydrolysis & 2.789 & 167349 & 9.408 & 24.659 & 9683 & 0.92 \\
\hline Alkaline hydrolysis & 2.799 & 156770 & 7.162 & 42.522 & 9210 & 0.91 \\
\hline $\begin{array}{l}\text { Oxidative } \\
\text { degradation }\end{array}$ & 2.770 & 161546 & 1.062 & 14.691 & 5127 & 0.94 \\
\hline $\begin{array}{l}\text { Photolytic } \\
\text { degradation }\end{array}$ & 2.755 & 170975 & 11.539 & 22.568 & 6148 & 1.04 \\
\hline Thermal degradation & 2.774 & 165013 & 8.988 & 19.732 & 8148 & 0.94 \\
\hline \multicolumn{7}{|c|}{ Forced degradation data of Elvitegravir } \\
\hline $\begin{array}{l}\text { Degradation } \\
\text { condition }\end{array}$ & $\begin{array}{l}\text { Retention } \\
\text { time (mins) }\end{array}$ & Area & Purity Angle & Purity Threshold & USP Plate Count & Asymmetry \\
\hline
\end{tabular}


A novel validated RP-UPLC-DAD method for the simultaneous estimation of Emtricitabine, ..

\begin{tabular}{|l|l|l|l|l|l|l|}
\hline Acid hydrolysis & 4.131 & 615800 & 0.384 & 1.302 & 9990 & 1.05 \\
\hline Alkaline hydrolysis & 4.118 & 638835 & 0.328 & 1.620 & 8091 & 1.0 \\
\hline $\begin{array}{l}\text { Oxidative } \\
\text { degradation }\end{array}$ & 4.109 & 645281 & 0.348 & 0.792 & 2152 & 0.92 \\
\hline $\begin{array}{l}\text { Photolytic } \\
\text { degradation }\end{array}$ & 4.097 & 676997 & 0.248 & 0.639 & 8334 & 1.03 \\
\hline Thermal degradation & 4.113 & 658773 & 0.319 & 0.781 & 8552 & 0.97 \\
\hline $\begin{array}{l}\text { Degradation } \\
\text { condition }\end{array}$ & Drug Recovered (\%) & Elvitegravir & Drug Decomposed (\%) & Elvitegravir \\
\hline & Cobicistat & 100 & 100 & 100 \\
\hline Standard & 100 & 90.79 & 2.24 & 9.21 \\
\hline Acid hydrolysis & 97.76 & 94.19 & 8.42 & 5.81 \\
\hline Alkaline hydrolysis & 91.58 & 95.14 & 5.63 & 4.86 \\
\hline $\begin{array}{l}\text { Oxidative } \\
\text { degradation }\end{array}$ & 94.37 & 99.81 & 0.12 & 0.19 \\
\hline $\begin{array}{l}\text { Photolytic } \\
\text { degradation }\end{array}$ & 99.88 & 97.12 & 3.60 & 2.88 \\
\hline Thermal degradation & 96.40 & & & \\
\hline
\end{tabular}

\section{Acknowledgement}

The authors are thankful to Malla Reddy College of Pharmacy for providing the chemicals and instruments and Hetero Drugs Limited, Hyderabad, India and Shilpa Medicare Limited, India for providing the drug samples for research.

\section{References}

[1]. J.L. Olin, L.M. Spooner and O.M. Klibanov, Elvitegravir / cobicistat / emtricitabine / tenofovir disoproxil fumarate single tablet for HIV-1 infection treatment, Annals of Pharmacotherapy, 46, 2012, 1671-1677.

[2]. C.M. Perry, Elvitegravir/cobicistat/emtricitabine/tenofovir disoproxil fumarate single-tablet regimen (Stribild ${ }^{\circledR}$ ): a review of its use in the management of HIV-1 infection in adults, Drugs, 74, 2014, 75-97.

[3]. N.L. Rezk, R.D. Crutchley and A.D.M. Kashuba, Simultaneous quantification of emtricitabine and tenofovir in human plasma using high-performance liquid chromatography after solid phase extraction, Journal of Chromatography B., 822, 2005, 201-208.

[4]. J.A.H. Droste, R.E. Aarnoutse and D.M. Burger, Determination of emtricitabine in human plasma using HPLC with fluorometric detection, Journal of Liquid Chromatography and Related Technologies, 30, 2007, 2769-2778.

[5]. V. Jullien, J.M. Treluyer, G. Pons and E. Rey, Determination of tenofovir in human plasma by high-performance liquid chromatography with spectrofluorimetric detection, Journal of Chromatography B.,785,2003,377-381

[6]. D. Ashenafi, A. Verbeek, J. Hoogmartens and E. Adams, Development and validation of an LC method for the determination of emtricitabine and related compounds in the drug substance, Journal of Separation Science, 32, 2009, 1823-1830.

[7]. R.W. Sparidans, K.M.L. Crommentuyn, J.H.M. Schellens and J.H. Beijnen, Liquid chromatographic assay for the antiviral nucleotide analogue tenofovir in plasma using derivatization with chloroacetaldehyde, Journal of Chromatography B., 791, 2003, 227-233.

[8]. M.E. Barkil, M.C. Gagnieu and J. Guitton, Relevance of a combined UV and single mass spectrometry detection for the determination of tenofovir in human plasma by HPLC in therapeutic drug monitoring, Journal of Chromatography B., 854, 2007, 192-197.

[9]. K.Y. Kavitha, G. Geetha, R. Hariprasad, R. Venkatnarayana and G. Subramanian, Development and validation of RP-HPLC analytical method for simultaneous estimation of emtricitabine, rilpivirine, tenofovir disoproxil fumarate and its pharmaceutical dosage forms, Pharmacie Globale, 4, 2013,1-9.

[10]. N. Raju and S. Begum, Simultaneous RP-HPLC method for the estimation of the emtricitabine, tenofovir disoproxil fumerate and efavirenz in tablet dosage forms, Research Journal of Pharmacy and Technology, 1, 2008, 522-525.

[11]. P.D. Hamarapurkar and Parate, An HPLC method for the determination of emtricitabine and related degradation substances, Journal of Chromatographic Science, 51, 2013, 419-424.

[12]. K. Mangaonkar and A. Desai, Simultaneous estimation of emtricitabine, tenofovir disoproxil fumarate and efavirenz from tablets by reverse phase high performance liquid chromatography method, Indian Drugs, 45, 2008, 188-192.

[13]. J.U.Seshachalam, B. Haribabu and K.B. Chandrasekhar, Development and validation of a stability-indicating liquid chromatographic method for determination of emtricitabine and related impurities in drug substance, Journal of Separation Science, 30, 2007, 999-1004.

[14]. A.K. Peepliwal and C.G. Bonde, Determination of emtricitabine in human plasma by RP-HPLC with UV-detection, Journal of Pharmacy Research, 3, 2010, 1712-1715.

[15]. A. Karunakaran, K. Kamarajan and V Thangarasu, Validated RP-HPLC method for simultaneous estimation of emtricitabine and tenofovir disoproxil fumarate in pure and in tablet dosage form, Der Pharmacia Sinica, 1, 2010, 52-60.

[16]. P. Kumar, S.C. Dwivedi and A. Kushnoor, A validated stability indicating RP-HPLC method for the determination of emtricitabine in bulk and capsules, Farmacia, 60, 2012, 402-410.

[17]. P.B. Kandagal, D.H. Manjunatha, J. Seetharamappa and S.S. Kalanur, RP-HPLC method for the determination of tenofovir in pharmaceutical formulations and spiked human plasma, Analytical Letters, 41, 2008, 561-570.

[18]. U.P. Panigrahy and A.S.K. Reddy, A novel validated RP-HPLC method for the simultaneous estimation of Emtricitabine, Tenofovir Disoproxil Fumarate and Rilpivirine in bulk and pharmaceutical tablet dosage forms, Der Pharmacia Lettre, 7, 2015, 303-314.

[19]. T. Delahunty, L. Bushman and C.V. Fletcher, Sensitive assay for determining plasma tenofovir concentrations by LC/MS/MS, Journal of Chromatography B., 830, 2006, 6-12.

[20]. N.A. Gomes, V.V. Vaidya, A. Pudage, S.S. Joshi and S.A. Parekh, Liquid chromatography-tandem mass spectrometry (LCMS/MS) method for simultaneous determination of tenofovir and emtricitabine in human plasma and its application to a bioequivalence study, Journal of Pharmaceutical and Biomedical Analysis,48,2008, 918-926. 
[21]. S. Chandni and M.A. Nazeeruddin, Development and Validation of a Simple UV-Spectrophotometric method for the determination of Cobicistat in its bulk form, Indo American Journal of Pharmaceutical Research, 4, 2014, 5792-5796.

[22]. M. Joshi, A.P. Nikalje, M. Shahed and M. Dehghan, HPTLC method for the simultaneous estimation of emtricitabine and tenofovir in tablet dosage form, Indian Journal of Pharmaceutical Sciences, 71, 2009, 95-97.

[23]. G.A. Shabir, Validation of high-performance liquid chromatography methods for pharmaceutical analysis. Understanding the differences and similarities between validation requirements of the US Food and Drug Administration, the US Pharmacopeia and the International Conference on Harmonization, J Chromatogr A., 987, 2003, 57-66. 